http://dx.doi.org/10.18232/alhe.1002

Artigos

\title{
Bunge e Sanbra: formação de grupos econômicos no Brasil (1923-1994)
}

\section{Bunge and Sanbra: Formation of Economic Groups in Brazil (1923-1994)}

Armando D. Costa ${ }^{1,} *$ (iD 0000-0002-1016-7491

Gustavo P. Silva ${ }^{2}$ iD 0000-0002-3943-6130

${ }^{1}$ Universidade Federal do Paraná, Curitiba, Brasil.

${ }^{2}$ Universidade Federal de São Carlos, Sorocaba, Brasil.

* Correspondencia: ajdcosta@uol.com.br

Resumo. Este artigo identifica os motivos que levaram a Sociedade Algodoeira do Nordeste Brasileiro, S. A. (Sanbra), subsidiária da Bunge Brasil, a se tornar um grupo econômico. Será analisada sua história de mais de 70 anos, de 1923 até 1994, quando a firma foi incorporada na reestruturação da Bunge. O artigo baseiase em fontes primárias consultadas no Centro de Memória Bunge, em São Paulo, sobretudo os Relatórios de Diretoria e Balanços Anuais e a revista Atualidades Sanbra. Teoricamente seguirá os autores que tratam da formação de business groups em economias periféricas. Como conclusão prévia pode-se afirmar que alguns fatores contribuíram para a transformação da Sanbra em grupo econômico, principalmente o reinvestimento do capital próprio, o lançamento de novos produtos, a atuação em diversos setores, relacionamento com fontes creditícias do Estado, assim como a ocupação do território nacional.

Palavras-chave: Bunge; Sanbra; grupos econômicos; agronegócio; algodão; soja.

CÓMO CITAR: Costa, A. D. e Silva, G. P. (2020). Bunge e Sanbra: formação de grupos econômicos no Brasil (1923-1994). América Latina en la Historia Económica, 27(1), e1002. DOI: 10.18232/alhe.1002 
Abstract. This paper identifies the motives that took Sociedade Algodoeira do Nordeste Brasileiro, S. A. (Sanbra), Bunge's subsidiary, to consolidate a business group. Their seventy-year history is analysed, from 1923 to 1994, when the company was incorporated in Bunge's restructuring. The article is based on primary resources, all consulted on Bunges's Memorial Center, in São Paulo, specially the balanços anuais (annual balances), the Relatórios de Diretoria e Balanços Anuais (board reports) and the magazine Atualidades Sanbra. The following authors will theoretically handle the business groups's formation in peripheral economies. As a forecast conclusion, it's able to confirm that some factors contribute for Sanbra's Business Groups transformation, specially the reinvestment of their own capital, launching new products, acting in several sectors, relationship with State credit sources, as their occupation in the national territory.

Key words: Bunge; Sanbra; business groups; agribusiness; cotton; soya.

JEL: N5; N56; N66.

Recebido: 17 de Julho de 2018.

Aceito: 24 de Outubro de 2018.

Publicado: 11 de Julho de 2018.

\section{INTRODUÇÃO}

A Bunge Brasil possui unidades e centros de distribuição, escritórios comerciais, estrutura portuária, industrialização de soja e trigo, mineração, produção de lecitinas, margarinas e maioneses, refino de óleo e produção de gorduras, unidades misturadoras de nitrogênio, fósforo e potássio (macronutrientes de fertilizantes) (Bunge. Brasil, 2013, p. 47). Ao todo, são mais de 100 instalações, entre fábricas, usinas, moinhos, portos, centros de distribuição e silos, em 17 estados das cinco regiões brasileiras e no Distrito Federal (Bunge. Brasil, 2014, p. 9).

A Bunge chegou ao Brasil associando-se ao Moinho Santista, em 1905, e cresceu diversificando atividades, comprando concorrentes, fazendo joint-ventures, inovando e lançando novos produtos 1 Passados mais de cem anos, já na década de 1990, a Bunge Brasil era um grupo econômico formado por 127 empresas, todas atuando de maneira independente e com suas próprias marcas e identidades corporativas (Bunge. Brasil, 2013, p. 31; Calais, 2017). ${ }^{2}$

A Sociedade Algodoeira do Nordeste Brasileiro, S. A. (Sanbra), que será estudada neste artigo, era uma destas subsidiárias, que chegou a constar entre as 30 maiores firmas do país, junto com o Moinho Santista e o Moinho Fluminense (portanto, a Bunge tinha três empresas entre as 30 maiores do Brasil), além de ser a maior exportadora de produtos do agronegócio e a terceira maior exportadora nacional nos anos 1970. Desde o início, ela foi a responsável pela atuação da Bunge Brasil no agronegócio algodoeiro, assim como no setor exportador.

Em que pese tamanha pujança no cômputo das empresas exportadoras nacionais, a bibliografia apresenta lacunas no entendimento de como se formou a Sanbra - na década de 1920 na cidade do Recife (estado de Pernambuco) - e quais os fatores que a tornaram uma das maiores firmas do

\footnotetext{
${ }^{1}$ A Bunge and Co. foi criada em Amsterdam (Holanda), em 1818, por Johann Peter Gotlieb Bunge para a exportação-importação de cereais. Em 1859, a mudou a sede para Antuérpia (Bélgica), mantendo, entretanto, a filial holandesa. Em 1884, Ernest Bunge, neto de Johann, juntou-se ao cunhado Jorge Born e criou a sociedade Bunge y Born na Argentina, coligada ao grupo na Europa e que, em 1897, veria a entrada dos alemães Alfredo Hirsch e George Oster como sócios, configuração societária responsável por trazer o Grupo ao Brasil (Barbero, 2013, p. 80).

${ }^{2} \mathrm{Na}$ classificação de Aldrighi e Postali (2010, pp. 355-357), constata-se que no ano de 2007, a Bunge era o $13^{\circ}$ maior grupo econômico do Brasil (segundo a receita bruta), no geral, e o maior grupo do setor alimentício.
} 
agronegócio brasileiro. Trabalhos como de Pinto (1969), Boldrin (2011) e Bini (2009) abordam a participação da Sanbra como firma exportadora de algodão e sisal em momentos específicos do século xx, em análises setoriais destes negócios agrícolas, sem efetuar um trabalho de maior monta sobre a Sanbra e suas empresas. Da mesma forma, há trabalhos como os de Shurtleff e Aoyagi $(2009 ; 2016)$ que abordam a Sanbra como exportadora do agronegócio brasileiro nas décadas de 1950 a 1970 -destacando a exportação de soja- mas, que o fazem de maneira diminuta, resumindo em poucas palavras o que foi toda a trajetória da empresa no século xx.

Diante desta lacuna, o objetivo principal deste artigo é explicar como a Sanbra, uma das subsidiárias da Bunge Brasil, constituiu-se num grupo econômico. Para tanto, será reconstituída sua história, desde a origem em Recife, em 1923, até o ano de 1994 quando, na reestruturação promovida pela Bunge, tal firma foi incorporada em outro setor de atividade. A pergunta chave que buscaremos responder é: quais fatores levaram a Sanbra a se transformar num grupo econômico, ou seja, como se formou um grupo nas entranhas de um já existente, a própria Bunge Brasil? O artigo investigará tanto a diversificação de atividades, o reinvestimento do capital próprio, a ocupação do território nacional, o faturamento no mercado interno e externo, seu relacionamento eventual com os órgãos de financiamento governamentais e, ademais, o lançamento de novos produtos como razões principais para transformar-se em um grupo econômico.

Com base em dados utilizada foi montada a partir de consulta a documentos primários disponíveis no Centro de Memória Bunge, na cidade de São Paulo. O artigo inicia com uma revisão teórica tratando dos autores que abordam a formação de grupos econômicos em economias periféricas. Segue mostrando como se constituiu a firma e sua atuação nas primeiras três décadas. $\mathrm{Na}$ terceira parte, destaca os motivos que a levaram a se transformar em um grupo econômico e finaliza com as conclusões.

\section{FORMAÇÃO DE GRUPOS ECONÔMICOS EM ECONOMIAS PERIFÉRICAS}

Segundo Colpan e Hikino (2010), os grupos econômicos se fizeram presentes como forma organizacional das empresas de economias, hoje tidas como emergentes, no decorrer do século xx, tendo um papel destacado no processo de industrialização de países como Brasil, Argentina, Chile, Coreia do Sul, China, Índia, México e outros..$^{3}$ Os grupos econômicos seriam uma resposta às imperfeições das economias de países atrasados: nações com baixa integração do mercado interno, escassez de fontes energéticas e creditícias, economias pouco industrializadas e com mão-de-obra concentrada no campo (Leff, 1974, p. 527; Valdaliso, 2002, p. 587).4

\footnotetext{
${ }^{3}$ Os grupos econômicos receberam diferentes nomenclaturas nos países emergentes: na Coreia do Sul são os chaebols; na Índia os business houses; na Turquia as holding companies; e, na América Latina, Brasil incluído, se consagrou o termo grupos econômicos (Kim, Kandemir e Cavusgil, 2004, p. 14).

${ }^{4}$ No caso da economia brasileira, pelo menos até o fim dos anos 1920, o quadro geral demonstrava uma economia primário-exportadora concentrada essencialmente na produção e venda de café -no ano de 1929, este produto representou 70\% do valor das exportações nacionais. Naquele momento, a agricultura respondia por $36 \%$ do produto interno bruto, enquanto a indústria por apenas 16\%. As empresas atuavam mais na esfera regional, pois o sistema de transporte, sobretudo as ferrovias, era relativamente pequeno - em 1930, a Argentina, com um território que é 33\% do brasileiro, tinha $38000 \mathrm{~km}$ de ferrovias, enquanto o Brasil tinha $32000 \mathrm{~km}$. Ademais, no que tange às matérias-primas e fontes energéticas, as indústrias brasileiras importavam mais de $80 \%$ dos aços laminados que consumiam, bem como boa parte do carvão, ambos vindos da Inglaterra (Barros, 2015, p. 182; Bértola e Ocampo, 2012, p. 95; Cunha, 1992, p. 356; Franco e Lago, 2012, p. 221; Saes, 2010, p. 218).
} 
Em que pesem as discordâncias acerca das definições, convencionou-se denominar como grupos econômicos a reunião de empresas juridicamente independentes que atuam de maneira conjunta, pois estão vinculadas de maneira formal (relações contratuais, patrimônio, controle do capital) ou informal (laços familiares) (Carney et al., 2011, p. 437; Colpan, Hikino e Lincoln, 2010, p. 6; Gonçalves, 1999, p. 181; Khanna e Yafeh, 2010, p. 576; Yaprak e Karademir, 2010, p. 247) ${ }^{5}$

Para Guillén (2000), os empresários criam grupos econômicos se as condições políticas e econômicas lhes permitem adquirir e manter a capacidade de combinar recursos -insumos, conhecimentos e mercados- para entrar em novos setores de atividades. A capacidade para combinar de forma rápida e eficiente estes recursos é genérica (na medida em que pode ser empregada para entrar em qualquer setor) e, ao mesmo tempo, muito específica de cada grupo. Inclui aspectos intangíveis: contatos, acesso a linhas de crédito privilegiadas e know how; e tangíveis: serviços, fatores e produtos, que podem proporcionar vantagens às empresas que já pertencem ao grupo.

Para Amsden e Hikino (1994, 1997), que basearam seus estudos em países de industrialização tardia (Coreia do Sul), a vantagem mais importante dos grupos sobre as empresas especializadas reside na disponibilidade de uma capacidade para executar projetos, que foi adquirida em atividades anteriores e que podem usar para entrar em novos setores onde não existem firmas estabelecidas.

Ademais, uma importante fonte de crescimento aos grupos econômicos pode vir de seu alinhamento às políticas nacionais desenvolvidas pelo Estado. No caso da América Latina -em países como o Brasil- o projeto de desenvolvimento econômico tendo como fio condutor a industrialização, a partir da década de 1930, foi realizado com uma participação estatal na economia que, na tentativa de internalizar setores industriais, estimulava a formação e atuação de grupos econômicos, tanto nacionais quanto estrangeiros, em seu modelo de state-led industrialization (Bértola e Ocampo, 2012, p. 138; Guillén, 2000, p. 366; Ocampo e Ros, 2011, pp. 4-14; Schneider, 2010, p. 662).

A organização destes grupos, segundo Colpan, Hikino e Lincoln (2010, p. 16), deu-se pela escolha de uma estrutura de propriedade piramidal, em que no vértice encontra-se uma empresa central (holding) - podendo ser uma família a controlar esta holding - a liderar as subsidiárias que atuam em setores cuja produção tende a ser não-relacionada, ou seja, há uma propensão dos grupos econômicos à diversificação produtiva 6 Esta tendência à formação de subsidiárias e à diversificação de produtos é característica dos grupos econômicos e lhes permitia: atuar em diversos setores; obter economias de escala e escopo através da melhor utilização de recursos internos; maior poder de mercado; diminuição de riscos; ganhos de aprendizado; além de maiores fontes de capitalização do grupo através dos lucros de suas subsidárias -compensando prejuízos com outras empresas do grupo (Delios e Ma, 2010, p. 721; Khanna e Yafhe, 2010, p. 579; Morck, 2010, p. 609).

\footnotetext{
${ }^{5}$ Esta definição de grupos econômicos dada por Khanna e Yafhe (2010) consolidou-se como a de maior difusão entre os analistas desta forma de organização empresarial, sendo replicada por trabalhos recentes, como em Coban (2017, p. 105) e Trindade (2017, p. 35).

${ }^{6}$ Morck (2010, p. 609) diz que a existência de empresas subsidiárias -que são juridicamente independentes- vinculadas a uma empresa-mãe (holding) é o que diferencia os grupos econômicos dos conglomerados, estes sendo as grandes empresas integradas verticalmente analisadas por Chandler (1962).
} 
No caso do Brasil, os grupos econômicos caracterizam-se pela atuação em, ao menos, três ramos industriais, sendo esta diversificação uma resposta às falhas de mercado -por exemplo, um incipiente mercado de capitais- que levou à formação de grandes e diversificados grupos econômicos, como a Bunge Brasil, em que a Sanbra era uma das subsidiárias (Aldrighi e Postali, 2010, p. 371) (ver tabela 1). 7

Bunge Brasil é um típico exemplo destes grupos; sua atuação se dava em diferentes setores: trigo, milho, café, algodão, sisal, mamona, oiticica, arroz, na industrialização e nas exportações; têxtil, químico, alimentício, cimento no setor industrial, para o abastecimento do mercado interno e exportações; logístico, com atuação nos aspectos rodoviário, ferroviário e marítimo; entre outros. Para entendermos o tamanho e a significação das empresas do Grupo Bunge no Brasil, basta analisarmos o tamanho de algumas delas, comparadas com as maiores firmas (ver tabela 2).

Ao mesmo tempo, estas empresas subsidiárias estavam sob o comando econômico e dirigidas por três famílias: Bunge, Born e Hirsch. Ao analisarmos de forma separada uma destas subsidiárias, a Sanbra, como faremos doravante, notamos que sua expansão foi também no sentido de se transformar em um grupo econômico -com suas próprias subsidiárias-coligadas- mantendo relações com a Bunge Brasil, ao mesmo tempo em que esta mantinha relações financeiras, executivas, de assistência técnico-operacional com a matriz Bunge \& Born argentina e aquela, por sua vez, com a Bunge de Antuérpia (Barbero, 2013; Born, 2008; Bunge. Brasil, 2013, p. 31; Green e Laurent, 1989; Silva e Costa, 2015).

\section{Constituição e início de atividades da Sociedade Algodoeira do Nordeste Brasileiro, S. A.}

A Sociedade Algodoeira do Nordeste Brasileiro, S. A. (Sanbra), como seu próprio nome diz, iniciou com atividades no ramo do algodão. Seu histórico teve início quando surgiu, em 1919 no Recife, a firma Cavalcanti \& Cia. Em seguida, "a Bunge adquire a empresa Cavalcanti \& Cia. que, em 1923, mudaria seu nome para Sanbra, tornando-se a primeira empresa da Bunge no segmento de oleaginosas" (Bunge. Brasil, 2012). Na mesma época de seu surgimento, "o caroço de algodão passou a ser usado para fins alimentares, através da extração e do refino do óleo” (Sanbra, 1973, pp. 12 e ss.) 8

Com apenas seis anos de existência a nova firma já lançava um produto pioneiro no mercado para atender à demanda doméstica. "Em 1929 a Sanbra lança o Salada, de algodão, primeiro óleo vegetal comestível fabricado no país. O óleo revolucionaria os hábitos alimentares de consumidores que na época usavam banha de porco" (Bunge. Brasil, 2012).

Para industrializar o caroço de algodão, a Sanbra implantou seu parque industrial no distrito de Areias, em Recife. Do caroço, além do óleo comestível e margarina, sabão, glicerina e outros produtos industriais, produzia torta e farelo, utilizado como ração animal e no preparo de fertilizantes.

\footnotetext{
${ }^{7}$ Entre os 50 maiores grupos econômicos atuando no mercado brasileiro no ano de 2007, quinze eram comandados por famílias nacionais, enquanto 21 eram controlados por firmas estrangeiras, que podiam ser familiares, como a Bunge, oito grupos eram dirigidos por companhias privadas e fundos de pensão nacionais, cinco grupos eram estatais e um era chefiado de maneira conjunta por uma família brasileira e uma empresa estrangeira (Aldrighi e Postali, 2010, p. 372).

${ }^{8}$ Os dados a respeito do histórico da Sanbra foram consultados em diversos materiais no Centro de Memória Bunge, São Paulo. As informações deste início de atividades no Recife, ver Sanbra (1973a).
} 


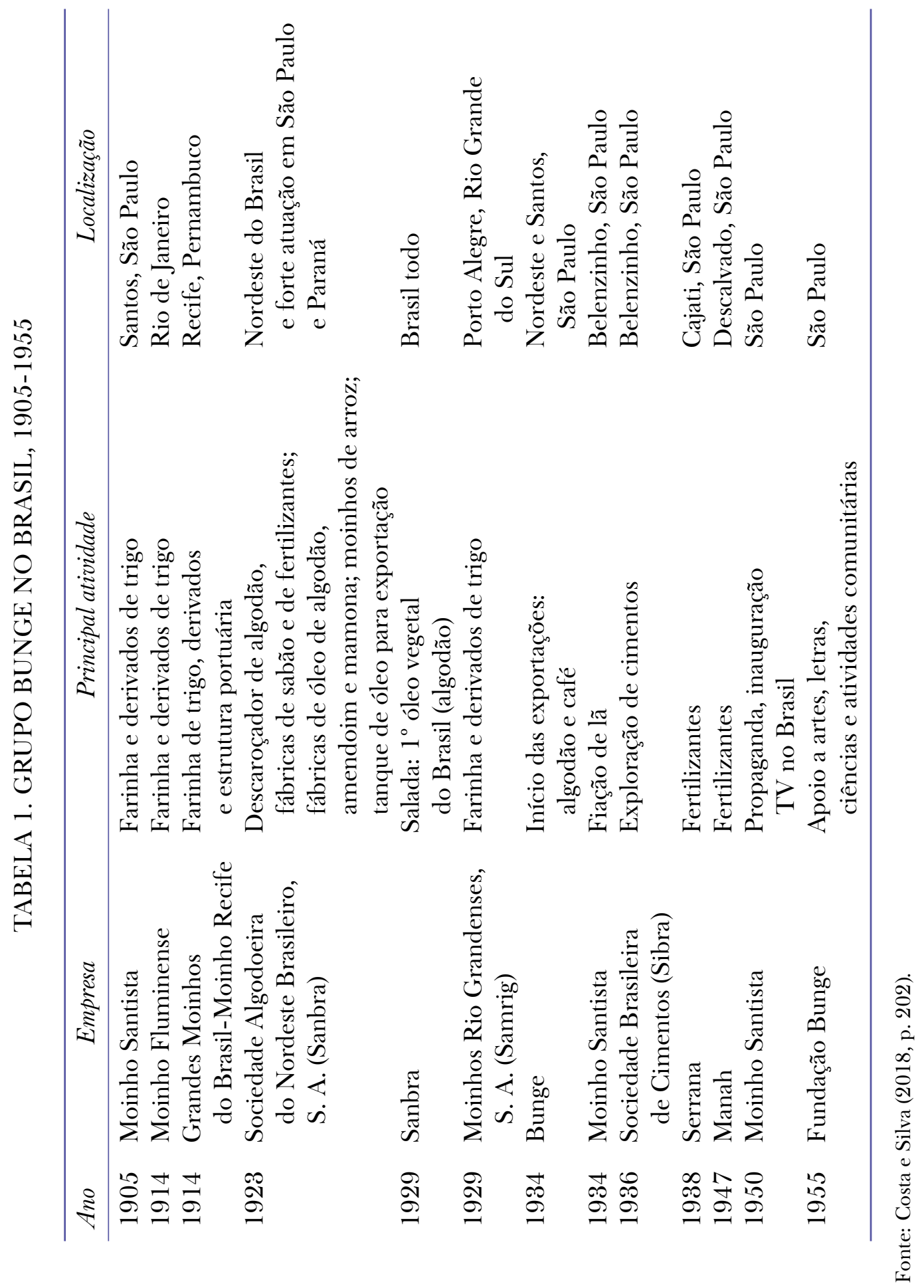


TABELA 2. VALOR DE MERCADO DAS EMPRESAS ABERTAS DE 1988

\begin{tabular}{clc}
\hline Entre 100 maiores & Empresa & \multicolumn{1}{c}{ Dólares } \\
\hline 1 & Petrobras & 1372258256 \\
31 & Moinhos Santista & 162861888 \\
32 & Moinho Fluminense & 161454182 \\
100 & Banco Mercantil & 31057446 \\
s. d. & Grupo Bunge & s. d. \\
s. d. & Sanbra & s. d. \\
\hline
\end{tabular}

Fonte: "Valor de mercado" (1988).

Em Campina Grande, na Paraíba, a Sanbra "instalou-se em 1935-1936 com um escritório de compra de algodão em pluma e mamona em bagas. Em fins de 1949 começou a operar a sua fábrica de óleos" (Sanbra, 1975b, p. 22). Pelos dados da revista, em 1975 o seu complexo industrial permitia o esmagamento de caroço de algodão, semente de oiticica $!^{9}$ amêndoas de babaçu 10 e tucum ${ }^{11}$ além de soja. Em 1958 teve suas instalações ampliadas, atingindo a capacidade de 130 t. per dia de caroço de algodão. Seus principais produtos eram óleos brutos, farelo, casca e linters. Normalmente, os óleos brutos eram transferidos para a refinaria de Areias, no Recife, enquanto o farelo de algodão era exportado. As instalações de Campina Grande, na Paraíba, empregavam, em 1975, mais de 200 pessoas.

Uma vez instalada no Nordeste, a Sanbra permanecia atenta às atividades de produção de algodão das demais regiões. O governo do estado de São Paulo, principal centro industrial brasileiro nos anos 1920 e importante produtor nacional de algodão, promoveu pesquisas e gerou melhorias na qualidade das fibras, melhorou as sementes e as distribuiu em grandes quantidades, posibilitando um sensível aumento na produção algodoeira (Dean, 1971, p. 20).12

Com o avanço do algodão no estado de São Paulo na década de 1930, a Sanbra expandiu suas atividades em direção a este estado e ao sul do país. "Em 1934 arrendou quatro usinas em Araraquara, Agudos, Cerqueira Cesar e Pirajuí. Em 1935 adquiriu sua primeira máquina de beneficiar aldogão em São Paulo, na cidade de Pederneiras. No Paraná, em máquina arrendada, na cidade de Wenceslau Braz, já em 1938 beneficiava algodão” (Sanbra, 1973a, p. 13).

\footnotetext{
${ }^{9}$ Oiticica é uma planta que pode atingir até quinze metros de altura, comum no nordeste brasileiro. Seus frutos podem ser utilizados para extração de corantes naturais e produção de biodiesel.

${ }^{10}$ Babaçu é uma planta da família das palmeiras, dotada de frutos com sementes oleaginosas e comestíveis das quais se extrai um óleo, empregado sobretudo na alimentação, remédios, além de ser alvo de pesquisas avançadas para a fabricação de biocombustíveis.

${ }^{11}$ Tucum é uma palmeira que atinge de dez a doze metros de altura. Cresce na Mata Atlântica, desde a Bahia até o Rio Grande do Sul. Produz pequenos cocos (com cerca de dois centímetros de diâmetro) que fornecem óleo alimentício.

${ }^{12}$ Entre 1929 e 1940, a participação brasileira nas áreas mundiais dedicadas ao plantio do algodão aumentou de $2 \%$ para $8.7 \%$, sendo que no rol dos produtos exportados, o algodão passou de uma média anual de $2.1 \%$ no final da década de 1920, para 18.6\% durante o período de 1935-1939 (Baer, 2014, pp. 50-52). Este avanço na produção contou com a sustentação de preços por parte do Estados Unidos; novos demandantes como o mercado alemão e japonês; além de fatores nacionais, como a expansão da indústria têxtil e da extração de óleos vegetais. Em São Paulo, o algodão que representava somente $1.7 \%$ do valor da produção agrícola estadual em 1931-1933, passou a marca de $7.8 \%$ no período 1936-1938 (Negri, 1996, pp. 73-74).
} 
A atuação em São Paulo e Paraná foi tão significativa que, combinando o volume de mercadorias adquiridas com sua industrialização, geração e comercialização de subprodutos, fez com que, em 1941, a sede da Sanbra fosse transferida para São Paulo.13 A expansão do grupo ficou marcada pela operação de aumento de seu capital em 21 de março de 1942, quando passou de 5000 contos (Rs. 5.000:000\$000) de réis para 20000 contos (Rs. 20.000:000\$000), através da subscrição de 15000 contos feita por dois acionistas: a Sociedade Anônima Moinho Santista com 10000 contos e a Fábrica de Tecidos Tatuapé, situada na cidade de São Paulo, com 5000 contos, sendo estas firmas duas subsidiárias do grupo Bunge Brasil ("Ata da Assembleia Extraordinária de Sanbra”, 1942, p. 32) ${ }^{14}$

Continuando sua expansão, em 1948 a Sanbra instalou no distrito do Jaguaré, na cidade de São Paulo, uma fábrica e uma refinaria de caroço de algodão. É interesante notar que a atuação empresarial é dinâmica e vai seguindo o curso das culturas e da oferta de matéria prima, como descrito pelos dirigentes: "as usinas de beneficiamento de algodão foram sendo instaladas, acompanhando a migração da cultura do algodão, sendo montadas e desmontadas à medida em que aumentava a produção numa região e diminuía em outra” (Sanbra, 1973a, p. 13).

Mantendo este mesmo espírito de acompanhar o deslocamento da produção pelo país, em 1956, de acordo com a mesma fonte, pelo aumento da produção no Paraná, a Sanbra construiu sua primeira usina em Maringá. Em seguida, unidades descaroçadoras de algodão foram montadas em Cianorte, Paranavaí, Assaí, Umuarama, Guaraci, Iporã, etc. Essas usinas criaram as condições para a edificação da Fábrica de Óleos de Maringá, cuja construção começou em 1960.

No estado de São Paulo, uma das cidades em que a empresa manteve maior presença e atuação foi Presidente Prudente. De acordo com Mendonça e Costa (2014, p. 10), neste município, "a Sanbra localiza-se na vila Maristela, na confluência das Ruas Alvino Gomes Teixeira com a Rua José Claro, às margens da linha férrea”. Esta localização era estratégica tanto pelo acesso à matéria prima, quanto pela via de escoamento dos produtos e proximidade com as demais indústrias de beneficiamento agrícola.

A Sanbra inaugurou sua atuação na cidade "em 1948, com atividades voltadas ao descaroçamento de algodão. No auge da produção, na década de 1950, a unidade chegou a contar com cerca de 300 funcionários' 15 (MPE cobra a revitalização de estrutura da Sanbra, 13 de fevereiro de 2014, p. 1b).

Além do algodão, a Sanbra começou a construção de refinarias para industrializar amendoim. "Em 1948 foram construídas três fábricas em Marília, Presidente Prudente e São Carlos, a primeira trabalhando só com amendoim e as outras duas também com caroço de algodão" (Sanbra, 1973c, p. 4). Pelos dados da mesma fonte, em março de 1953, a Sanbra adquiriu as fábricas de Ribeirão Preto, Bauru e Ourinhos e instalou uma refinaria de óleo em Tatuapé, bairro da cidade de São Paulo. Em 1951, inaugurou a Fábrica de Óleo de Campina Grande, na Paraíba

\footnotetext{
${ }^{13}$ De acordo com seus documentos, "a matriz ficou em São Paulo, enquanto as filiais estavam distribuídas no Rio de Janeiro, Salvador, Recife, João Pessoa, Campina Grande, Natal e Fortaleza” Sanbra ([1954], p. 27).

${ }^{14}$ Entre os acionistas presentes na assembleia da Sanbra de 21 de março de 1942 estavam: Bunge y Born Ltda. Sociedade Anónima, Comercial, Financiera e Industrial; Idrys Howell; Santiago Antich; Sociedade Financeira e Industrial Sud Americana; Antonio Pinto da Silveira Figueiredo; Jorge de Sousa Rezende; Luiz de Moraes Barros.

${ }^{15}$ Número de funcionários que foi crescendo na Sanbra, passando de $5490 \mathrm{em} 1960$ (Sanbra, 1960, p. 6) para 7940 em 1967 (Sanbra, 1967, p. 6) para atingir, na Bunge Brasil, 18353 em 2013 (Bunge. Brasil, 2014, p. 11).
} 
Analisando a atuação da Sanbra a nível nacional, é possível perceber como foi construindo, nas suas primeiras três décadas (1923-1953), uma rede abrangente, atendendo todo Brasil. São Paulo, tanto em função da produção de algodão -e outros produtos também industrializados pela Sanbra, como amendoim, mamona, arroz e milho- como pela sua importância em termos de indústrias e de mercado consumidor, tornou-se o centro de suas atividades. Neste estado passaram a funcionar "7 fábricas de óleo de amendoim e caroço de algodão, 1 fábrica de óleo de mamona, 2 moinhos de arroz, 30 descaroçadores de algodão, 7 depósitos, 1 tanque de óleo para exportação, 3 prensas de alta densidade, 3 refinações de óleos vegetais e fábricas de sabão" (Sanbra, [1954], s. p.).

Enquanto São Paulo destacava-se pela quantidade de instalações, Pernambuco tomou a dianteira no sentido da diversificação, constituindo-se no estado em que a Sanbra mantinha quantidade maior de itens comprados, produzidos e comercializados. Entre suas atividades, destacavam-se “ 5 depósitos, 3 descaroçadores de algodão, 1 fábrica de óleo de algodão, 1 fábrica de óleo de mamona, 1 tanque de óleo para exportação, 1 prensa de alta densidade, 1 fábrica de óleo de extração por solvente, 1 fábrica de fertilizantes, 1 refinação de óleo e 1 fábrica de sabão" (Sanbra, [1954], s. p.).

Mesmo com um volume e uma diversificação de atividades menor, a Sanbra fez-se presente em diversos outros estados, a saber: Paraíba, onde contava com "9 depósitos, 6 descaroçadores de algodão, 1 prensa de alta densidade, 1 fábrica de óleo de caroço de algodão”. Na Bahia detinha "2 depósitos", enquanto outros três estados do nordeste contavam com apenas uma atividade, ou seja, "1 depósito em Alagoas, Rio Grande do Norte e Ceará” (Sanbra, [1954], s. p.).

Campina Grande, na Paraíba, era conhecida como a Liverpool brasileira, considerada o segundo pólo de comércio de algodão a nível internacional. Foi atrás desta produção de matéria prima que a "Sanbra chegou à cidade em 1935, onde construiu uma grande estrutura" (Araújo e Sousa, 2015). Neste local operou um depósito, um descaroçador de algodão, uma prensa de alta densidade e uma fábrica de óleo de caroço de algodão

Na década de 1940 a Sanbra iniciou, em Recife, a extração do óleo de mamona. Para tanto, adquiriu no bairro de Boa Viagem, uma fábrica de óleo cujas instalações permitiram o iníco da atividade, "até a construção de nova fábrica no bairro industrial de Areias, inaugurada em 1948". Dando continuidade à produção, a Sanbra iniciou, em 1955, a construção de nova fábrica de óleo de mamona em Salvador (Sanbra, 1968).

\section{SANBRA TRANSFORMA-SE EM GRUPO ECONÔMICO NA SEGUNDA METADE DO SÉCULO XX}

Em seguida o texto buscará esclarecer os principais elementos que levaram a Sanbra a transformarse em grupo econômico. Dentre eles, destacam-se a diversificação de atividades e produtos; o reinvestimento do capital próprio; a ocupação do território nacional; as exportações e o faturamento no mercado interno.

\section{Sanbra cresce diversificando atividades, produtos e ocupando território nacional}

Como já foi mencionado, a Sanbra iniciou suas atividades no ramo do algodão em 1923. De acordo com Delios e Ma (2010), um grupo econômico pode crescer através da diversificação de suas atividades, forjando uma estrutura industrial mais integrada, por exemplo, rumando em direção à garantia do fornecimento de sua matéria prima. 
Analisando a documentação, percebe-se que a Sanbra atuava tanto para frente como para trás na cadeia produtiva. Começava pela parte genética de seleção, multiplicação e distribuição de sementes de mamona e outros vegetais através de seu Departamento Técnico Agronômico, cujos integrantes estavam capacitados a prestar a assistência técnica necessária aos agricultores e às entidades envolidas com a produção agrícola $\sqrt{16}$ "Além desta ação direta a Sanbra participa do INFAOL -Instituto Nordestino para o Fomento de Algodão e Oleaginosas-, entidade criada sob inspiração direta da Sanbra e que atualmente atua em nove estados nordestinos, com o apoio das Secretarias de Agricultura destes Estados, do Conselho Monetário Nacional e dos Bancos Central, do Brasil e do Nordeste" (Sanbra, 1975a, p. 23).

Uma vez garantida a qualidade, distribuição e produção da matéria prima, era necessário encarregar-se da sua compra junto aos produtores, tanto no Nordeste como nos demais estados do Centro-Oeste, Sudeste e Sul onde passou a atuar. Após longo processo de melhoramento e extensão de sua rede, as agências de compras chegaram a um total de 30, presentes em nove estados, com destaque para o Paraná (catorze) e São Paulo (dez) (ver tabela 2 e mapas 1 e 2).

Depois de adquirida a matéria-prima, o proceso de industrialização iniciava-se com a separação do caroço e da pluma. Para esta finalidade, a Sanbra chegou a contar no início da década de 1980 (ver tabela 2), com 25 usinas de beneficiamento de algodão em nove estados.

O parque fabril da Sanbra contava com nove plantas industriais entre fábricas de óleos comestíveis e industriais; refinarias de óleos comestíveis, em cinco estados. Neste caso, a diversificação de produtos apresenta outros aspectos, uma vez que tais plantas industriais também estavam capacitadas para produzir óleos e demais subprodutos, além do algodão, a partir do milho, amendoim, oiticica, mamona e arroz. Desta maneira, conforme a quantidade produzida em cada safra e a disponibilidade de outras matérias primas, a Sanbra aproveitava tanto suas instalações industriais, máquinas e equipamentos, como seus operários para diminuir o tempo de capacidade ociosa e aumentar o faturamento e lucro. Esta participação da Sanbra na cadeia algodoeira -uma integração vertical- corrobora a ideia de Delios e Ma (2010, p. 722) acerca da maior possibilidade de crescimento do grupo através da diversificação em atividades relacionadas, até um ponto ótimo em que os retornos seriam decrescentes.

Por fim, não basta apenas produzir mercadorias. É necessário que elas cheguem aos pontos de venda e ao consumidor final. A Sanbra foi construindo uma rede de unidades de vendas que chegou a nove, estrategicamente distribuídas entre sete estados, de tal forma que conseguissem atender a demanda de todo território nacional. Sua documentação assim descreve a logística de distribuição: "a Sanbra distribui seus produtos para o país inteiro, através de uma rede de promotorias de vendas próprias, localizadas no Rio de Janeiro, Belo Horizonte, Ribeirão Preto, Bauru, Ourinhos e Santos. O transporte dos produtos é feito através de ferrovias ou por frota própria de caminhões" (Sanbra, 1970a, pp. 3, 5, 15).

A revista destaca que praticamente todo Brasil era atendido. A promotoria do Rio de Janeiro atende a Guanabara, o estado do Rio de Janeiro, do Espírito Santo e o norte de Minas Gerais. A de Bauru, além da região, atende parte do Mato Grosso. A de Ourinhos, o Norte do Paraná e parte do Mato Grosso. A de Ribeirão Preto, o Estado de Goiás. O litoral sul paulista é atendido

\footnotetext{
${ }^{16}$ Também nos anos 1930, o Grupo Votorantim, em meio à crise econômica do início da década, estreitou os laços com seus fornecedores de algodão no interior de São Paulo -concedendo sementes e mesmo financiando parte das safras- para garantir o suprimento de matéria-prima para a principal empresa do grupo naquele momento, a Fábrica Têxtil Votorantim (Silva e Costa, 2015, p. 13).
} 


\section{MAPA 1. SANBRA E SUAS ATIVIDADES ADMINISTRATIVAS NO BRASIL, 1972}

Limites estaduais

Atividades administrativas

Agências de compras

Chefia Regional/Agência Vendas

Chefia Regional/Agência Vendas/Escritórios

$\bigcirc$ Sede

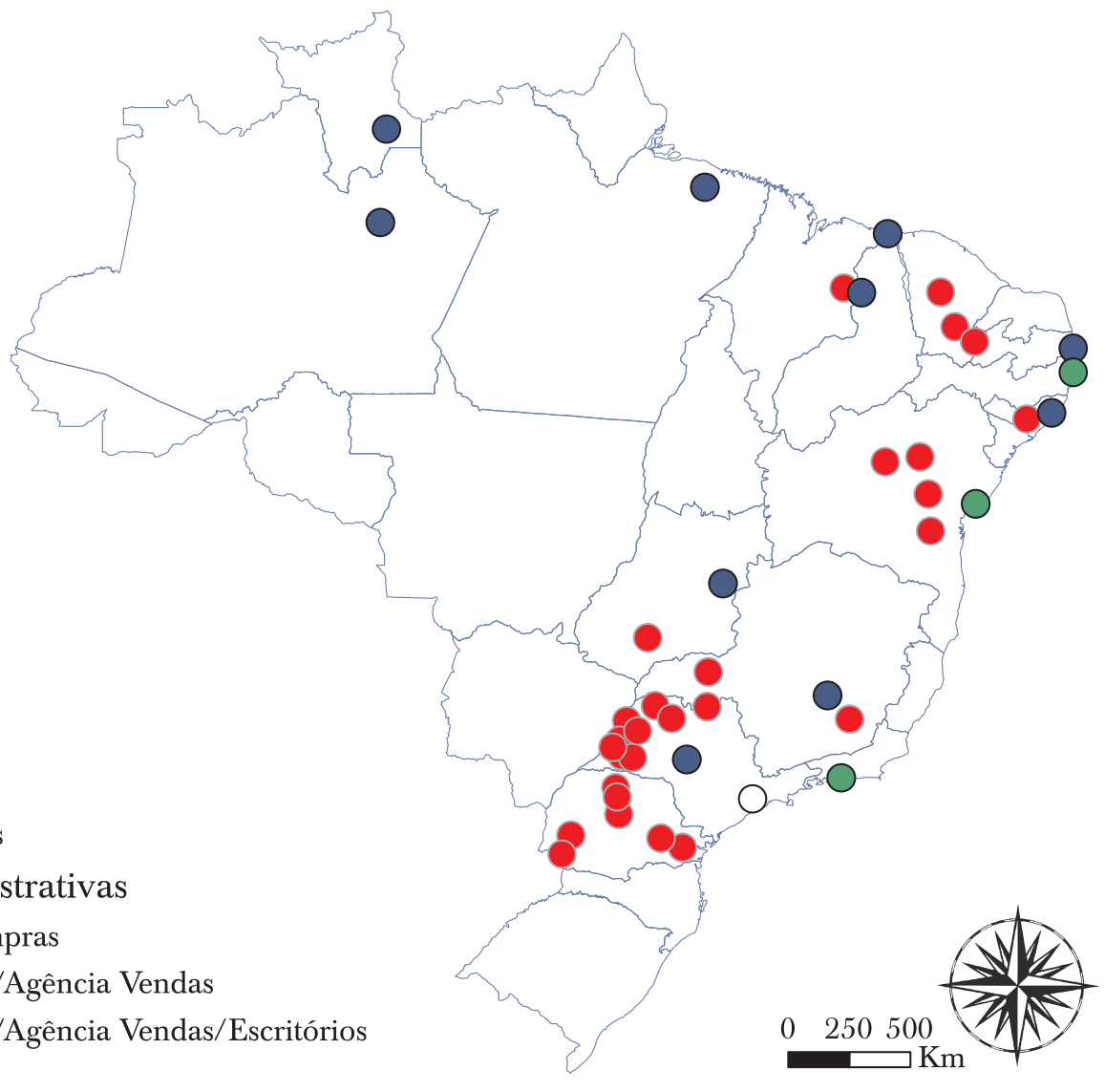

Fonte: elaboração própria com base em Sanbra (1960-1985).

pela de Santos e o restante de Minas Gerais pela promotoria de Belo Horizonte. São Paulo atende a região de Campinas, o sul de Minas Gerais e o litoral norte do Estado. A região norte do país é atendida pela filial Sanbra de Recife (ver mapas 1 e 2).

Analisando-se os mapas 1 e 2 percebe-se que as principais atividades da Sanbra estão localizadas em duas regiões: Nordeste e Sudeste. No Nordeste a firma mantinha fortes atividades tanto do ponto de vista da recepão de diversas matérias primas (algodão, sisal, mamona) como para atender, com produtos industrializados, aquela região e o Norte do Brasil. Os estados de São Paulo e Paraná, no Sudeste-Sul, concentravam ao mesmo tempo, a recepção de matérias primas (algodão, café, milho, soja) e representavam o local onde se encontrava o maior mercado consumidor a nível nacional. 


\section{MAPA 2. SANBRA E SUAS ATIVIDADES INDUSTRIAIS NO BRASIL, 1972}

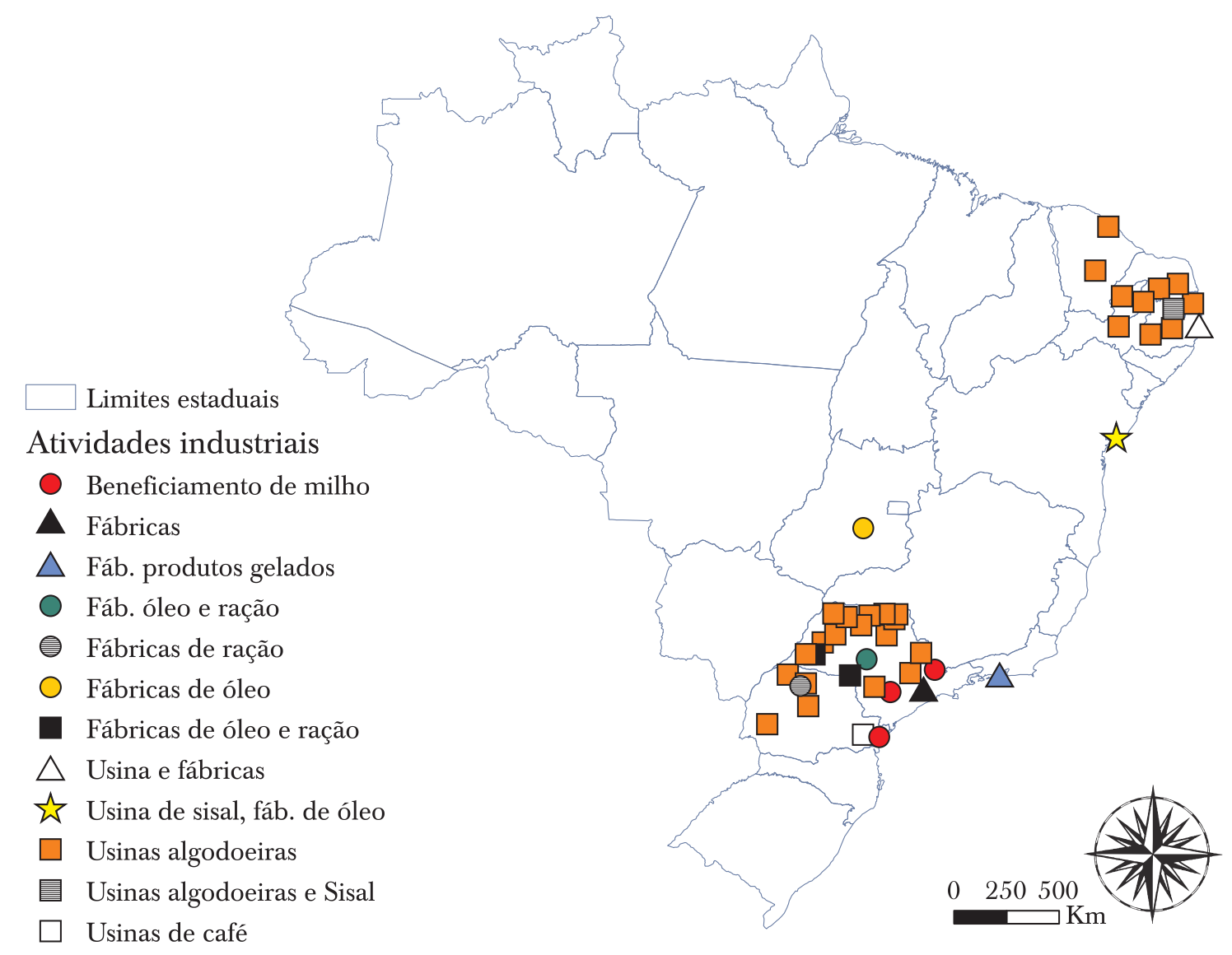

Fonte: elaboração própria com base em Sanbra (1960-1985).

A diversificação de atividades $\sqrt{17}$ no caso da Sanbra, aconteceu tanto em direção a outros produtos, além do algodão (milho, soja, arroz, mamona, oiticica, girassol, gergelim, dendê, sisal, café, exportações), como na industrialização e lançamento de novas mercadorias, evidência demonstrada pela descrição de uma de suas fábricas, a de Jaguaré, em São Paulo.

Em 1960, a Sanbra iniciou, no bairro de Jaguaré, na cidade de São Paulo, em um terreno de $180000 \mathrm{~m}^{2}$, a construção de um parque industrial. "Ele compreendia as fábricas de: margarina; gordura; sabão e sub-produtos industriais; refinaria de óleos comestíveis; unidade de extração de óleo de mamona; e cinco laboratórios para controle de qualidade e pesquisa" (Sanbra, 1970b, p. 6).

\footnotetext{
${ }^{17}$ No histórico da Sanbra houve momentos de maior diversificação no setor agroindustrial ao expandir sua atuação para outras matérias primas como algodão, sisal, mamona; expansão para outras regiões, como nos anos 1930 quando se deu o deslocamento para o sudeste e; por fim, um movimento no sentido de agregar mais valor às mercadorias, quando a Bunge intensificou seu processo de industrialização a partir da década de 1950.
} 
Em 1961, o parque industrial do Jaguaré contava com $22000 \mathrm{~m}^{2}$ de área construída e iniciou o refino de óleo de amendoim. Em 1962, começou a fabricação de margarina. Em 1967, entrou em funcionamento a fábrica de imidazolinas, que permitem a produção de inibidores de algas, emulsionantes para asfalto, auxiliares têxteis.

A Sanbra, que já produzia óleo vegetal desde a década de 1930, com as marcas Salada e Delícia, aumentou a produção, a partir da expansão da soja, lançando o óleo Soberbo em 1966 e, no ano seguinte, o óleo Primor, ambos de soja e o óleo Pérola, de milho. No campo das margarinas, possuía a Delícia, lançada em 1962 à qual juntou-se a Primor, a partir de 1967.

Um produto exótico para onde a Sanbra diversificou suas atividades foi a semente de oiticica, da qual passou a extrair o óleo na fábrica de Sapé, em 1962, cujas instalações transferiu para o Parque Industrial de Campina Grande, na Paraíba. Já a planta industrial de Recife, no início da década de 1970, "contava com 500 funcionários e produzia óleos comestíveis à base de sementes oleaginosas de caroço de algodão, amendoim, soja, girassol, gergelim, com uma capacidade de produção de 40000 toneladas-ano" (Sanbra, 1971, p. 7).

A diversificação de atividades da Sanbra reflete a política adotada pela Bunge Brasil em sua atuação geral e com as demais empresas: "[a Bunge] processa produtos como soja e trigo, comercializa açúcar, produz fertilizantes, fabrica produtos alimentícios (óleos, gorduras vegetais e margarinas), fornece farinha de trigo e pré-misturas para o setor de transformadores (indústrias de panificação e alimentação fora do lar) e fornece serviços portuários" (Sediyama, Castro Júnior, Calegario e Siqueira, 2013, p. 173).

Por vezes, a diversificação de atividades aparecia por obrigação legal, como foi a atividade da Sanbra em reflorestamento. Com este objetivo e, "atendendo às disposições da Lei 4.771, arts. $20^{18}$ e 21, de 15 de setembro de 1965 e Portaria n. 2.919 de 31 de junho de 1972, a Sanbra iniciou atividades de reflorestamento no Estado de São Paulo. Para este fim, arrendou 1816 hectares de terra e já iniciou o plantio de 4540000 árvores" (Sanbra, 1960-1985 [1973, p. 20]).

A tabela 3 sistematiza a diversificação empreendida pela Sanbra e que a levou a atuar em doze atividades diferentes, mas relacionadas, ajudando a compreender como ocupou o território nacional, através de sua presença em doze estados. Esta atuação espalhada pelo país veio como uma resposta às demandas regionais que puderam ser abastecidas pela Sanbra. Neste sentido, para criar suas novas estruturas produtivas nos Estados, aproveitava-se do fornecimento local de matérias-primas, mas também, de sua expertise, mão-de-obra já treinada, capitais acumulados, capacidades que, como Guillén (2000) e Colpan, Hikino e Lincoln (2010, p. 43) demonstram, davam uma vantagem competitiva e um maior poder de mercado aos grupos econômicos.

$\mathrm{Na}$ análise da tabela 3, chamam atenção diversos aspectos. O primeiro é a tentativa da Sanbra de acompanhar o desenvolvimento das atividades econômicas nos diversos Estados. Tendo começado suas atividades no Nordeste e para trabalhar com algodão e derivados atuava, em 1980, em doze Estados, com destaque para São Paulo, Paraná, Pernambuco e Bahia.

O Nordeste continuou sendo importante, em função das atividades com algodão, sisal, oiticica, mamona e derivados. No entanto, os dois Estados que concentraram a atuação da Sanbra foram São Paulo e Paraná. Neste caso, o algodão, acompanhando a origem da empresa, foi o motivo

${ }^{18}$ O Art. 20 dizia: “As empresas industriais que consumirem grande quantidade de materia prima florestal são obrigadas a manter um serviço organizado que assegure o plantio de novas áreas, em terras próprias ou de terceiros, cuja produção seja equivalente ao consumido para o seu abastecimento”. 


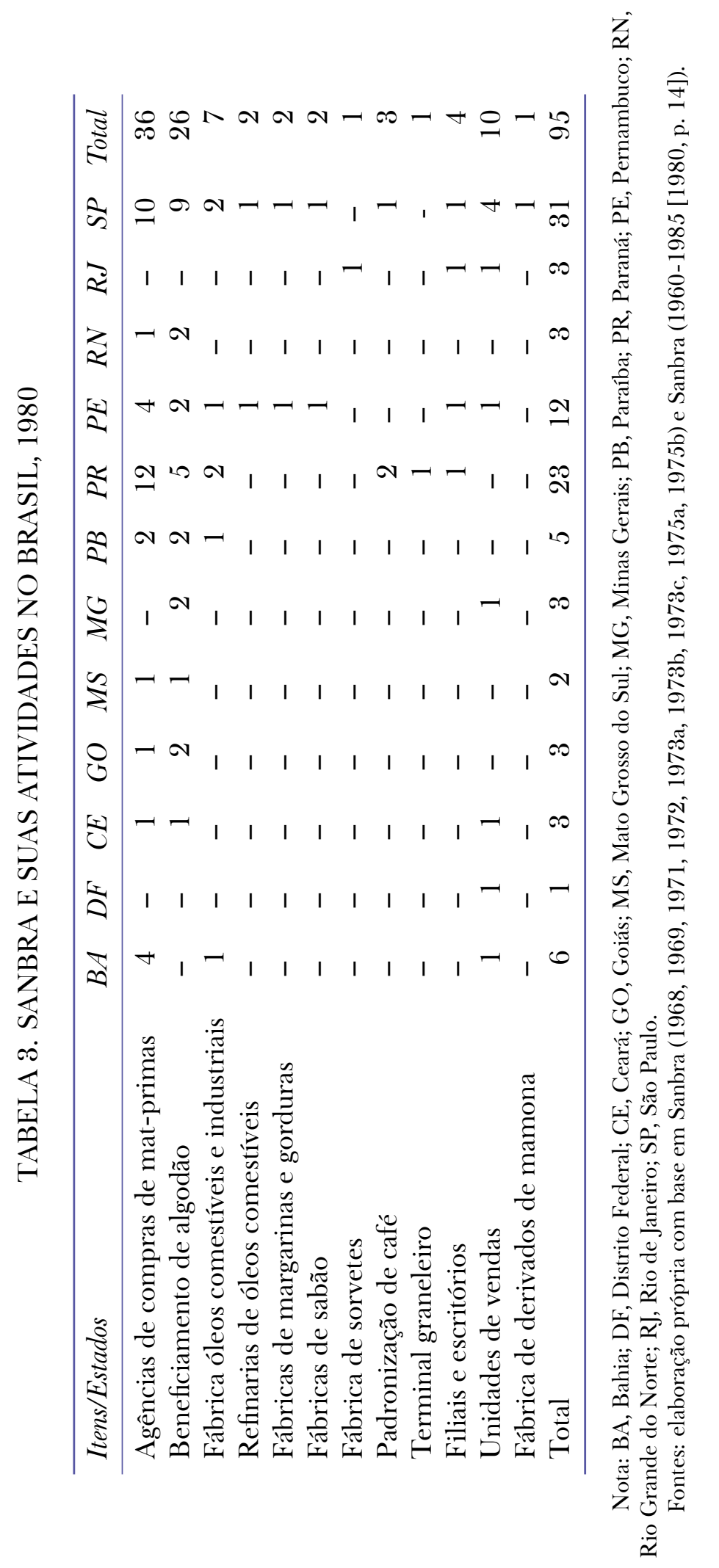


inicial, entretanto, dois outros produtos contribuíram para atrair a Sanbra a esta região: café e soja. No último caso, a Sanbra atuou tanto na compra como na industrialização e geração de subprodutos, destinados ao mercado interno e às exportações 19

No Rio de Janeiro, que era pouco representativo na produção de algodão e soja, a presença da Sanbra justificava-se pela diversificação de produtos destinados ao mercado carioca. Foi nas proximidades daquela cidade que a firma instalou sua primeira fábrica de sorvetes para atender a demanda interna e externa.

Outro destaque é a quantidade de lugares onde a Sanbra estava presente em 1980. Trata-se de 95 atividades econômicas em diferentes cidades, regiões ou estados. Esta capilaridade contribuiu para estar presente nos principais centros de produção de matéria prima, assim como estabelecendo pontos de distribuição de seus derivados para atingir a demanda do mercado interno, uma vez que se trata de um país de dimensões continentais.

\section{Sanbra: o reinvestimento do capital próprio}

$\mathrm{O}$ aumento da receita como do lucro foi uma das fontes que permitiu à Sanbra reinvestir em coligadas e no seu próprio parque industrial (ver tabela 4). Outra observação é que, além do reinvestimento, por se tratar de uma empresa de capital aberto, lançava ações que depois distribuíam os lucros aos seus detentores.

Dos investimentos em coligadas é uma forma de garantir a diversificação de atividades, ocupar o território nacional, ofertar novas mercadorias e atender a demanda de diversos setores de consumo (ver tabela 5 ).

Contando com as Tintas Cora 20 (onde a Sanbra tinha cerca de 50\% do capital) e a Lubeca Administradora de Bens (cerca de 40\% do capital), percebe-se que, tomando o ano de 1984, os investimentos nas Tintas Coral foram de 31.3\%, enquanto na Lubeca Administradora de Bens foi de $34.3 \%$ representando, em ambas, $65.6 \%$ do total. Portanto, as maiores inversões em coligadas concentraram-se naquelas em que a Sanbra era acionista majoritária ou tinha mais ações investidas. Por outro lado, chamam a atenção, os investimentos na S. A. Moinho Santista Indústrias Gerais e S. A. Moinhos Riograndenses que, somados, significaram 24.1\% do total. Neste caso, mais significativo ainda, pois trata-se de outras duas subsidiárias do grupo Bunge Brasil e onde a multinacional é acionista majoritária.

Analisando os dados da Sanbra nas tabelas 3 e 4 percebe-se que ela se preocupou em gerar riqueza para ser reinvestida e aplicou recursos em outras firmas coligadas, além de imobilizar capital em terrenos, edifícios, máquinas e equipamentos. Esta capacidade de mobilização de capitais próprios por parte da Sanbra para se expandir e, ao mesmo tempo, robustecer a acumulação de sua holding, a Bunge Brasil, é atinente ao que Morck (2010) propõe sobre a aptidão dos grupos econômicos piramidais, formados pelas respectivas subsidiárias, em atuar em diversos setores, gerar capitais e mitigar as crises do grupo, sobretudo considerando as eventuais dificuldades no acesso ao crédito em economias em desenvolvimento.

\footnotetext{
${ }^{19}$ Entre os anos 1955-1975, São Paulo e Paraná foram os dois principais estados produtores de café no Brasil (Cunha, 1992, pp. 314-315).

${ }^{20}$ Em outubro de 1955 começou a funcionar a primeira fábrica das Tintas Coral. Suas origens estão ligadas à Argentina, onde a Bunge y Born mantinha, desde o final da década de 1920, a fábrica de tintas Alba S. A. Os primeiros executivos da Tintas Coral pertenciam ao Moinho Santista, enquanto que o arcabouço tecnológico e científico foi garantido pelos químicos e técnicos da Alba (Bunge. Brasil, 2013, pp. 12-13).
} 


\section{TABELA 4. SANBRA: RECEITA, LUCRO E LUCRO POR AÇÃO 1973-1984 (VALOR EM DÓLARES AMERICANOS, APRIL, 2016)}

\begin{tabular}{lccc}
\hline Anos/Itens & $\begin{array}{c}\text { Receita operacional } \\
\text { bruta(1 000) }\end{array}$ & $\begin{array}{c}\text { Lucro líquido } \\
(1 \text { 000) }\end{array}$ & $\begin{array}{c}\text { Lucro por ação } \\
\text { (lote de 1 000 ações) }\end{array}$ \\
\hline 1973 & 1756 & 13311 & 2 \\
1974 & 2390 & 23131 & 3 \\
1979 & 1629 & 16142 & 0 \\
1980 & 1721 & -9056 & 0 \\
1981 & 2056 & 74614 & 0 \\
1982 & 1938 & 89094 & 0 \\
1983 & 1916 & 144897 & 0 \\
1986 & 2129 & 49362 & 15 \\
1987 & 1392 & 43871 & 14 \\
1988 & 1056 & 66310 & 21 \\
1989 & 748.8 & 105040 & 33 \\
1990 & 769.1 & 18466 & 6 \\
1991 & 792.7 & 96331 & 30 \\
1992 & 618.3 & 29873 & 9 \\
\hline
\end{tabular}

Nota: como os valores nos documentos originais estão na moeda corrente da época (cruzados, novos cruzeiros e cruzeiros), para facilitar a compreensão, em algunas tabelas eles foram todos convertidos a dólares com o câmbio de abril de 2016.

Fonte: elaboração própria com base em Sanbra (1960-1985 [1972, p. 25; 1973, p. 30; 1974, p. 25; 1975, p. 20; 1980 , p. $15 ; 1982$, p. $19 ; 1983$, p. $20 ; 1984$, p. $18 ; 1987$, p. $53 ; 1988$, p. 12; 1989, p. 13, 1991, p. 4; 1992, p. 3]).

\section{Sanbra e a industrialização por substituição de importações}

O processo de industrialização de nações latinoamericanas, como o Brasil, adotou a industrialização por substituição de importações como seu fio condutor. Neste modelo, ocorre uma tentativa por etapas, lideradas pelo Estado, da formação de um tecido industrial completo dentro da nação, protegendo as empresas já existentes - por exemplo, via tarifas de importação sobre bens de consumo assalariados- para que ocupem faixas maiores da oferta nacional e, dessa forma, as divisas possam ser direcionadas para setores industrais em formação, caso dos bens de capital e intermediários 21

Neste processo dinâmico da substituição de importações, o Estado tem um papel fundamental ao articular as alianças entre suas empresas estatais, o capital privado nacional e o capital estrangeiro. No Brasil, esta articulação ficou clara durante a implementação do projeto industrializante do governo Juscelino Kubitschek (1956-1961): o Plano de Metas, com seus investimentos em energia ( $42 \%$ da estimativa do total a ser investido), transporte (29\%), indústria básica (22\%), alimentação (4\%) e educação (3\%) (Draibe, 1985, p. 241; Orenstein e Sochaczewski, 1989, p. 177).22

\footnotetext{
${ }^{21}$ Sobre as origens do processo de industrialização por substituição de importações, ver Tavares (1977).

${ }^{22}$ O Plano de Metas marca o período inicial da industrialização pesada no Brasil, quando ela se voltou aos bens de capital e bens de consumo duráveis - este o ramo industrial de maior crescimento entre 1956-1961. No período, os investimentos passaram de $13.5 \%$ para $18 \%$ do PIB e se concentraram na indústria que, em 1960 já respondia por $32 \%$ do
} 
O setor público seria o grande responsável pelo financiamento do Plano, cabendo a ele 50\% dos desembolsos. O capital privado, tanto nacional quanto estrangeiro, seria estimulado a investir a partir do financiamento estatal vindo de bancos públicos nacionais, o Banco Nacional de Desenvolvimento Econômico y Social (BNDEs) criado em 1952, além do crédito vindo do Banco do Brasil. ${ }^{23}$ Estes capitais deveriam voltar-se às áreas prioritárias elencadas no Plano e, na medida do possível, direcionando o crédito ao capital privado nacional, uma vez que, o BNDEs concedia avais para que as subsidiárias de empresas estrangeiras pudessem captar financiamento no exterior (Orenstein e Sochaczewski, 1989, p. 177; Willis, 2014).24

A disputa pelos financiamentos do BNDEs era intensa, pois estes créditos tinham uma taxa de juros de $11 \%$ ao ano, enquanto a inflação entre 1956-1960, teve média de $25 \%$ no Brasil, determinando um subsídio ao investimento industrial. Para obtenção dos empréstimos, mais importante até que a origem do pleiteante -pois, a priori, não haveria uma restrição ao capital estrangeiroera enquadrar os projetos aos setores entendidos como prioritários pelo banco: metalurgia do cobre, do alumínio e suas ligas; siderurgia (aços especiais); produção de ácido sulfúrico; produção de amoníaco sintético; produção de álcalis; indústria de fertilizantes; indústria de material elétrico pesado; indústria de material ferroviário; indústria de máquinas agrícolas e veículos automotores (Banco Nacional de Desenvolvimento Económico e Social [em diante BNDES], 1996, pp. 94-97).

O empréstimo obtido pela Sanbra no valor de 200000000 de cruzeiros, em que pese não ter sido o maior dentre os valores financiados, foi ilustrativo do peso exercido por um grupo econômico em meio ao projeto industrializante brasileiro. Como verificou-se antes, a Sanbra utilizou os capitais do BNDES para a construção do parque industrial do Jaguaré, na cidade de São Paulo, em uma planta industrial de $22000 \mathrm{~m}^{2}$ cuja finalidade era: refino de óleo de amendoim, fabricação de margarina, fábrica de imidazolinas e óleos, ou seja, atividades que não seriam prioritárias, de acordo com as arroladas inicialmente pelo BNDEs. Ademais, a maioria das empresas era de capital nacional e a Sanbra, por sua vez, era uma subsidiária da Bunge Brasil que, não se deve olvidar, era vinculada ao grupo Bunge y Born da Argentina.

O fato de não estar entre as áreas industriais prioritárias do Plano de Metas fazia com que uma alternativa fosse enquadrar o projeto como atendimento ao capital nacional, condição que também não era atendida pela Sanbra na visão dos técnicos do BNDES, que alegavam ser um grupo multinacional. Estes dois argumentos basearam a negativa dos técnicos aos empréstimos (Willis, 2014).

Eu diria que o maior debate econômico em termos de discussão filosófica ocorreu na aprovação do projeto da Sanbra. O projeto da Sanbra, que era uma multinacional, foi aprovado [...]. Mas houve uma longa e complexa discussão na diretoria entre o

PIB -à agricultura cabia 17\%. No agregado, a economia brasileira se expandiu a uma média de 8.2\% entre 1956-1961, enquanto o crescimento médio da América Latina foi de 5.2\% (Giambiagi, Villela, Castro e Hermann, 2005, p. 403; Mello, 2009; Serra, 1982, p. 77).

${ }^{23}$ Outra fonte de financimento vinha dos empréstimos de bancos públicos regionais, como o Banco de Desenvolvimento do Paraná. Em 1963, a Sanbra construiu sua fábrica de óleo em Maringá, cujas instalações foram ampliadas em 1969. Foram construídos dois novos silos, com capacidade de estocar, cada um, 30000 toneladas de soja ou 20000 toneladas de caroços de algodão, "com recursos provenientes do [Banco de Desenvolvimento do Paraná]” (Sanbra, 1969, p. 4).

${ }^{24}$ É importante ressaltar que a principal medida para estimular a entrada do investimento direto estrangeiro no Brasil durante o governo Kubitschek foi a Instrução 113 da Superintendência da Moeda e do Crédito (Sumoc), ao permitir a importação de máquinas e equipamentos sem cobertura cambial, como demonstram Caputo e Melo (2009). 


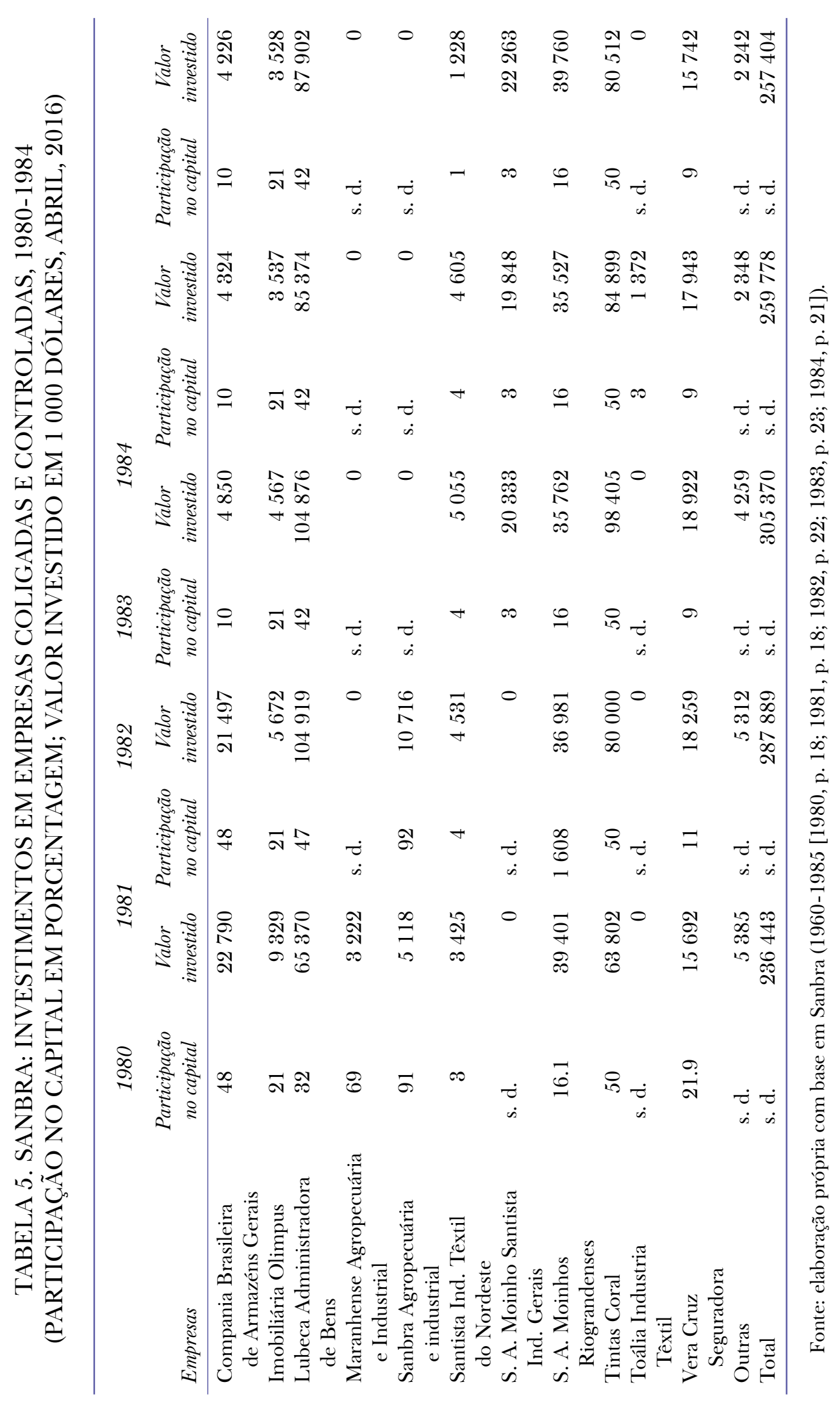




\section{TABELA 6. PROJETOS APROVADOS PELO BNDE NO ANO DE 1960 (VALORES EM MILHARES DE CRUZEIROS)}

\begin{tabular}{|c|c|c|c|}
\hline Entidades Financiadas & Valor & Estado & Descrição \\
\hline Farloc do Brasil, S. A. & 19158 & Rio de Janeiro & Indústria \\
\hline Ishikawajima do Brasil, S. A. & 500000 & Rio de Janeiro & Indústria \\
\hline Ishikawajima do Brasil, S. A. & 145000 & Rio de Janeiro & Indústria \\
\hline Força e Luz do Pará, S. A. & 319000 & Pará & Energia \\
\hline $\begin{array}{l}\text { Sociedade Algodoeira } \\
\text { do Brasil (Sanbra) }\end{array}$ & 200000 & São Paulo & Indústria \\
\hline Indústria de Papel Simão, S. A. & 160000 & São Paulo & Indústria \\
\hline $\begin{array}{l}\text { Usina Termelétrica } \\
\text { de Figueira (Utelfa) }\end{array}$ & 273000 & Santa Catarina & Energia \\
\hline $\begin{array}{l}\text { Empresa Sul Brasileira } \\
\text { de Energia, S. A. }\end{array}$ & 39700 & Santa Catarina & Energia \\
\hline Santa Lucia Cristais, S. A. & 27000 & São Paulo & Indústria \\
\hline Frigorífico Mouran, S. A. & 46500 & São Paulo & Indústria \\
\hline Fiação Brasileira de Sisal (Fibrasa) & 20500 & Paraíba & Indústria \\
\hline $\begin{array}{l}\text { Centrais Elétricas } \\
\text { Matogrossenses, S. A. }\end{array}$ & 594000 & Mato Grosso & Energia \\
\hline $\begin{array}{l}\text { Companhia Vale do São Francisco } \\
\text { (Três Marias) }\end{array}$ & 580000 & Minas Gerais & Energia \\
\hline Companhia Comércio e Navegação & 477000 & Rio de Janeiro & Portos e navegação \\
\hline $\begin{array}{l}\text { Administração do Porto } \\
\text { do Rio de Janeiro }\end{array}$ & 200000 & Distrito Federal & Portos e navegação \\
\hline Cobrasma & 41000 & São Paulo & Indústria \\
\hline Escelsa & 268087 & Espírito Santo & Energia \\
\hline Peixoto Gonçalves Navegação, S. A. & 20000 & Sergipe & Portos e navegação \\
\hline Mafrisa-Matad. Frirgorífico, S. A. & 123000 & São Paulo & Indústria \\
\hline Central Elétrica do Piauí & 26730 & Piauí & Energia \\
\hline
\end{tabular}

Fonte: BNDES (1996, p. 161).

Sr. Roberto Campos e o Dr. Ewaldo Correia Lima, então diretor substituto -e aí foram aos fundamentos da economia, foi uma discussão realmente memorável. O projeto da Sanbra foi aprovado na diretoria -e aí eu estou falando de memória, posso estar equivocado- por três a dois. Foi realmente uma discussão filosófica em termos do conceito de desenvolvimento econômico e se era importante financiar projetos de capital estrangeiro ou não... (BNDES, 1996, p. 96).

A negativa dos técnicos ao projeto da Sanbra foi revertida na diretoria do banco por margem apertada -três votos a dois- e contou com dois apoios importantes, além do próprio presidente do BNDES, Roberto Campos, que defendia a entrada mais robusta do capital estrangeiro na industrialização nacional (Madi, 2007, pp. 368-370). Um dos apoiadores foi Augusto Frederico Schmidt, prestigiado assessor do governo Juscelino Kubitschek -era assessor de Relações Internacionais- e 
que tinha um escritório na cidade do Rio de Janeiro que prestava consultoria técnica às empresas estrangeiras que queriam investir no Brasil. Sua amizade com Juscelino lhe permitiu solicitar ao presidente que usasse de sua influência para modificar a decisão dos técnicos do BNDEs e, dessa forma, levar ao resultado final favorável ao empréstimo para a Sanbra (Calicchio, 2001; Willis, 2014).

Este resultado monstra como a intimidade política foi elemento favorável à expansão dos grupos econômicos em meio ao processo de industrialização por substituição de importações, como apontam Schneider (2010, pp. 658-659) e Guillén (2000, p. 366). ${ }^{25}$ De uma parte, o governo estimulava a diversificação produtiva, pois mesmo que a Sanbra concentrasse suas atividades no setor de processamento de alimentos, devemos considerar que a Bunge Brasil, sua controladora, tinha uma atividade mais diversificada -como mostra a tabela 2 no início. Do ponto de vista do grupo Bunge Brasil, ele encontrava no Estado os recursos financeiros a um menor custo de captação se comparado ao mercado creditício de uma nação em desenvolvimento, o que está indicado na tabela 6. Mesmo assim a Bunge recorreu tanto a financiamento interno como externo.

Esta fusão de capital próprio com acesso ao crédito institucional, interno ou externo, era que possibilitava aos grandes grupos econômicos uma expansão contínua em economias que se encontravam em formação (Guillén, 2000, p. 367) 26

A partir da década de 1970, as exportações da Sanbra estavam consolidadas tanto a nível de produtos como na logística de embarque: "Mensalmente saem dos portos da Sanbra de 35 a 60 navios transportando fibra de algodão, óleo de mamona, café, milho, sisal, amendoim, soja e farelos em geral. Os 1971 embarques são realizados nos portos de Santos, Paranaguá, Rio de Janeiro, Natal, Recife e Fortaleza" (Sanbra, 1972, p. 6).

\section{Sanbra e sua atuação no mercado interno e externo}

O viés exportador da Bunge Brasil, controladora da Sanbra, vinha desde a década de 1930, com a venda ao mercado europeu de algodão em pluma sendo que, atualmente, o grupo é o principal exportador do agronegócio brasileiro (Bunge. Brasil, 2012). As exportações que começaram pelo algodão, depois também foram para outros produtos, tanto em forma de matérias primas como subprodutos industrializados 27

em 1960 começamos as exportações de café após cuidadosos estudos desta atividade, desde a compra ao produtor até a instalação de máquinas beneficiadoras. Estas foram instaladas nos centros de produção, como Catanduva, Valparaíso, Maringá e Cianorte, nos estados de São Paulo e Paraná. Para viabilizar as exportações, abrimos filial em Santos e um departamento de café na nossa filial do Rio de Janeiro (Sanbra, 19601986: 1960, p. 6).

\footnotetext{
${ }^{25}$ Segundo Willis (2014), “O empréstimo à Sanbra foi o mais direto exercício de influência pessoal por parte do presidente em nome de uma companhia privada durante os anos 1950”.

26 "Para complementar as necesidades de nosso movimento comercial e industrial temos contado com créditos rotativos, dos quais $28.5 \%$ são provenientes de bancos do país e $71.5 \%$ obtidos em bancos estrangeiros" (Sanbra, 1963, p. 7).

${ }^{27}$ O Centro de Memória Bunge, em São Paulo, preserva vários livros com todas as cartas enviadas aos "Exmos Srs. Bunge \& Born Ltda. em Buenos Aires”, mostrando um vínculo muito próximo entre os dirigentes da Bunge no Brasil e os da Argentina. Para uma primeira análise destas cartas, ver Costa e Silva (2018, pp. 199-209).
} 
TABELA 7. MAIORES EMPRESAS EXPORTADORAS BRASILEIRAS EM 1971

\begin{tabular}{|c|c|c|}
\hline Empresa & $\begin{array}{c}\text { Participação } \\
\text { (em } 1000 \text { dólares) }\end{array}$ & Percentagem \\
\hline $\begin{array}{l}\text { Compañia Vale do } \\
\text { Rio Doce }\end{array}$ & 190.7 & 6.63 \\
\hline $\begin{array}{l}\text { Instituto do Açúcar } \\
\text { e do Álcool }\end{array}$ & 146.7 & 5.10 \\
\hline Sanbra & 85.2 & 2.96 \\
\hline Petrobras & 39.9 & 1.39 \\
\hline $\begin{array}{c}\text { Industria e Comercio } \\
\text { de Minérios, S. A. }\end{array}$ & 36.4 & 1.26 \\
\hline $\begin{array}{l}\text { Sociedade Anónima } \\
\text { Frigorífico Anglo }\end{array}$ & 30.2 & 1.05 \\
\hline $\begin{array}{c}\text { Anderson Clayton S. A. } \\
\text { Industria e Comércio }\end{array}$ & 26.9 & 0.93 \\
\hline Compañia Swift do Brasil & 25.4 & 0.88 \\
\hline Frigorífico Bordon & 24.1 & 0.83 \\
\hline Frigorífico Armour & 21.1 & 0.73 \\
\hline
\end{tabular}

Fonte: elaboração própria com base em Sanbra (1960-1985 [1972, p. 23; 1973, p. 27; 1974, p. 22; 1975 , p. $22 ; 1976$, p. $19 ; 1977$, p. $19 ; 1978$, p. 19; 1979, p. 18; 1980, p. 12]).

Uma vez consolidadas as exportações em diversos produtos e a partir dos principais portos, a Sanbra tornou-se uma das maiores exportadoras nacionais 28 (ver tabela 7 ).

No setor algodoeiro, as duas maiores empresas eram a Sanbra e a Anderson Clayton (grupo estadunidense), estavam entre as maiores exportadoras nacionais nos anos 1970 (ver tabela 7). O domínio destas duas firmas sobre a produção e o beneficiamento do algodão era tido como um monopólio por parte de produtores e políticos nacionais, que condenavam tais práticas desde meados da década de 193029

As exportações da Sanbra tinham como destaque o café que, nos anos 1970, ainda era o principal produto na pauta exportadora nacional (ver tabela 8). Apesar da Sanbra responder por apenas $1.5 \%$ das exportações em 1980, foi onde mais faturou no comércio internacional. Em contrapartida, seu índice de exportação mais elevado foi na venda de óleo de mamona onde, entretanto, seu retorno monetário foi pouco significativo.

\footnotetext{
${ }^{28}$ Aliás, a documentação da firma iniste em dizer que a Sanbra era "a maior exportadora privada do agronegócio", uma vez que a Vale e o Instituto do Açúcar e do Álcool, suas concorrentes e maiores exportadoras, eram estatais (Carteira de Comércio Exterior do Banco do Brasil, 1971).

${ }^{29}$ No 11 de novembro de 1936, Mariano Wendell, deputado, indicava o processo de trustificação que ocorria na lavoura algodoeira paulista e de outros Estados, como a Paraíba. Segundo ele, "A instalação das grandes usinas destas firmas determinou o fechamento dos pequenos descaroçadores, ficando as sementes, tão necessárias ao alimento dos rebanhos, no poder daqueles polvos, que exigem por elas preços tão exorbitantes [...] Anderson Clayton \& Cia. e Sanbra já se encontram perfeitamente aparelhados para destruírem o que nos tem custado longos anos de labuta contínua e penosa" (Wendell, 1936, p. 9).
} 
As exportações da empresa mostram também seu poder de inovação e lançamento de novos produtos. "Alemanha Ocidental, Inglaterra, China, Peru e Argentina começaram a receber, em 1973, as primeiras remessas de lecitina de soja produzida no complexo industrial de Ponta GrossaPR. Os portos de Santos, Paranaguá e Porto Alegre, estão exportando um total de 100 ton-mês” Sanbra (1973b, p. 17).

Analisando vinte anos do faturamento da Sanbra (1962-1984), percebe-se que as exportações lhe renderam uma média de $40.1 \%$ do faturamento total, com picos de $49.8 \%$ na década de 1960 (ver tabela 9). Este papel gerador de divisas era fundamental à industrialização por substituição de importações, ao permitir deslocar cambiais para a importação máquinas, equipamentos e insumos (Fishlow, 2013, p. 28). Entretanto, no início da década de 1990, notamos que houve uma tendência declinante na importância das exportações, que se fixaram ao redor de 22 por cento.

As exportações da empresa mostram também seu poder de inovação e lançamento de novos produtos. "Alemanha Ocidental, Inglaterra, China, Peru e Argentina começaram a receber, em 1973, as primeiras remessas de lecitina de soja produzida no complexo industrial de Ponta GrossaPR. Os portos de Santos, Paranaguá e Porto Alegre, estão exportando um total de 100 ton-mês” Sanbra (1973b, p. 17).

Analisando vinte anos do faturamento da Sanbra (1962-1984), percebe-se que as exportações lhe renderam uma média de $40.1 \%$ do faturamento total, com picos de $49.8 \%$ na década de 1960 (ver tabela 9). Este papel gerador de divisas era fundamental à industrialização por substituição de importações, ao permitir deslocar cambiais para a importação máquinas, equipamentos e insumos (Fishlow, 2013, p. 28). Entretanto, no início da década de 1990, notamos que houve uma tendência declinante na importância das exportações, que se fixaram ao redor de 22 por cento.

A queda de faturamento no início da década de 1990 foi marcada pelo processo de reestruturação das empresas do Grupo Bunge: Sanbra, Samrig, Moinho Fluminense e Moinho Recife 30 Essas ações tinham como objetivo focar os investimentos da Bunge em agronegócio e alimentos. As primeiras mudanças ocorreram quando a Sanbra incorporou a Samrig e alterou a sua denominação social para Sanbra Alimentos, S. A., conforme a Assembleia Geral Ordinária e Extraordinária, de 27 de abril de 1994.

Em 13 de setembro do mesmo ano, a Sanbra Alimentos, S. A. alterou sua denominação social para Santista Alimentos, S. A. Após um mês foi incorporada pelo Moinho Fluminense mantendo a mesma razão social devido à importância da marca no mercado. Paralelamente, o Moinho Fluminense incorporou as participações no setor de alimentos do Moinho Recife, S. A. Empreendimentos e Participações e da S. A. Moinho Santista Indústrias Gerais. A reestruturação societária iniciada neste ano reduziu o número de empresas da Bunge de 32 para oito, aumentando o capital social da companhia. As mudanças tornaram a Santista Alimentos uma das maiores companhias brasileiras em seu segmento (Bunge. Brasil, 2013, p. 26). Através desta reestruturação, a Sanbra deixou de existir enquanto empresa individual e suas atividades foram incorporadas pela Bunge Brasil.

\footnotetext{
${ }^{30}$ Gaggero e Rougier (2017, pp. 417-418) apontam que na Argentina houve um processo de reestruturação dos grupos econômicos na década de 1990, com a bancarrota e venda de vários grupos nacionais para multinacionais.
} 


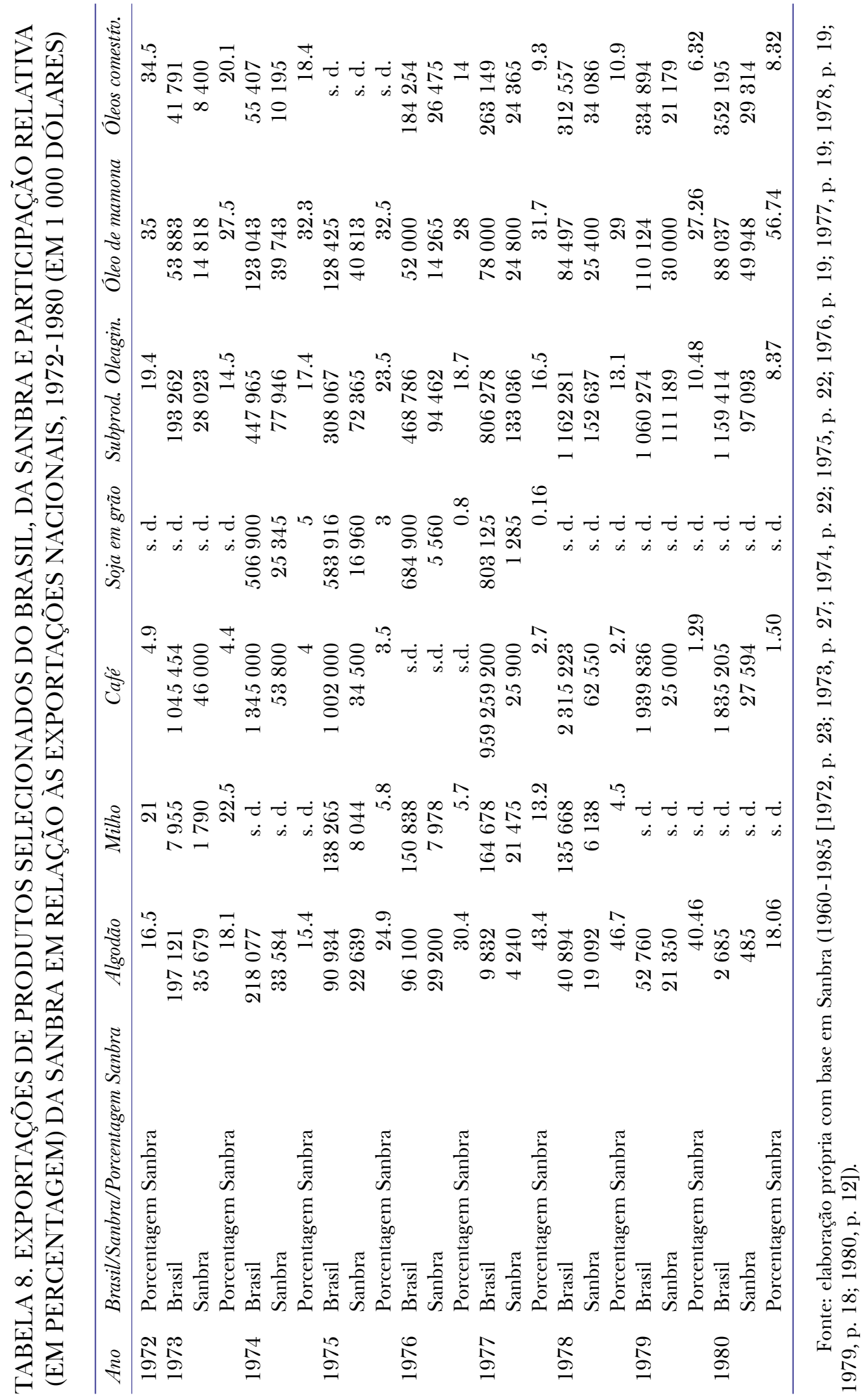


TABELA 9. SANBRA: FATURAMENTO TOTAL, BRASIL E EXTERIOR (1962-1984) (EM DÓLARES DE ABRIL DE 2016)

\begin{tabular}{|c|c|c|c|c|c|}
\hline Anos & Total & Brasil & $\begin{array}{c}\text { Porcentage } \\
\text { Brasil }\end{array}$ & Exterior & $\begin{array}{c}\text { Porcentage } \\
\text { exterior }\end{array}$ \\
\hline 1962 & 535241136 & 320462934 & 58.1 & 214778203 & 41.9 \\
\hline 1963 & 470188778 & 283064034 & 59.8 & 187124743 & 40.2 \\
\hline 1964 & 673804637 & 406184786 & 60.2 & 267619851 & 39.8 \\
\hline 1965 & 701030677 & 409190829 & 58.3 & 291839841 & 41.7 \\
\hline 1966 & 494099437 & 445316148 & 58.4 & 340793878 & 41.6 \\
\hline 1967 & 823363070 & 494748826 & 56.6 & 328614244 & 43.4 \\
\hline 1968 & 1195274807 & 652619979 & 60.1 & 542654828 & 39.9 \\
\hline $1969-1970$ & 136043547 & 718052967 & 54.6 & 642380581 & 45.4 \\
\hline $1970-1971$ & 1483829994 & 787951508 & 56.2 & 695530129 & 43.8 \\
\hline 1971-1972 & 1756593026 & 1059924322 & 53.1 & 696668705 & 46.9 \\
\hline $1972-1973$ & 2390591346 & 1221978107 & 60.3 & 1168613240 & 39.7 \\
\hline $1973-1974$ & 2321916532 & 1545951635 & 51.1 & 775964897 & 48.9 \\
\hline 1974-1975 & 1918356707 & 1218205873 & 66.6 & 700151243 & 33.4 \\
\hline $1975-1976$ & 2315993037 & 1421853140 & 63.5 & 894139897 & 36.5 \\
\hline $1976-1977$ & 2112649115 & 1298637057 & 61.4 & 814012058 & 38.6 \\
\hline $1977-1978$ & 1626345525 & 1089584331 & 61.4 & 926949779 & 38.5 \\
\hline 1978-1979 & 1934330550 & 1405687220 & 67 & 528643331 & 33 \\
\hline 1982 & 1946908992 & 1262273353 & 72.6 & 6503261245 & 27.3 \\
\hline 1983 & 2054080630 & 1457394729 & 65.6 & 596685902 & 34.4 \\
\hline 1984 & 1873731495 & 1351667479 & 70.9 & 522064016 & 29.1 \\
\hline 1986 & 323125531 & 223734850 & 72.1 & 99390680 & 27.9 \\
\hline 1987 & 2872239975 & 1866015226 & 65 & 1006224749 & 35 \\
\hline 1988 & 2767503000 & 1839827000 & 66.5 & 927677000 & 34.5 \\
\hline 1989 & 2631254994 & 1942432598 & 73.8 & 688822396 & 26.2 \\
\hline 1990 & 8912599675 & 6835591184 & 76.7 & 2077008491 & 23.3 \\
\hline 1991 & 1841306393 & 1388445137 & 75.4 & 452858199 & 24.6 \\
\hline 1992 & 1698344342 & 1335166781 & 78.6 & 363177561 & 21.4 \\
\hline
\end{tabular}

Fonte: elaboração própria com base em Sanbra (1960-1985 [1962, p. 21; 1963, p. 7; 1964, p. 9; 1965, p. 12; 1966 , p. $7 ; 1967$, p. $7 ; 1968$, p. $11 ; 1969$, p. $16 ; 1970$, p. $16 ; 1974$, p. $20 ; 1975$, p. $20 ; 1978$, p. $17 ; 1979$, p. 18 ; 1983 , p. $19 ; 1984$, p. $17 ; 1986$, p. 19; 1987, p. 51; 1989, p. $9 ; 1991$, p. $3 ; 1992$, p. 2]).

\section{ConsideraÇões finais}

A história da Sanbra é característica de uma empresa que iniciou atuando apenas no setor de algodão e, com o tempo, transformou-se num grupo econômico - um grupo dentro de outro, que era a Bunge Brasil. Conseguiu transformar-se em grupo econômico através, sobretudo, da diversificação de atividades, reinvestindo o capital próprio, atuando como uma das companhias que 
colaborou com a "industrialização através da substituição de importações", ocupando o território nacional, lançando e relançando novos produtos e fazendo-se presente no mercado internacional através das exportações

A diversificação de atividades levou a Sanbra a atuar, além do algodão, com outras matérias primas: milho, trigo, café, mamona, girassol, dendê, amendoim, oiticica, arroz e, já no século xxI, cana de açúcar. Ademais, ela também diversificou em produtos, entrando em novos setores, como margarinas, óleos vegetais, sabões e sorvetes.

O reinvestimento do capital próprio foi outra constante na Sanbra ao buscar constituir-se como grupo econômico. Destaca-se, neste caso, o investimento em itens fundamentais para a continuidade de seu crescimento, tais como terrenos, edifícios, máquinas e equipamentos e "obras em andamento", que mereceram a maior fatia dos recursos.

Ocupar o território nacional foi outra estratégia. Em 1980, ela contava com 95 atividades econômicas e estava presente em doze estados. Suas atividades avançaram para ocupar mais de 100 instalações, entre fábricas, usinas, moinhos, portos, centros de distribuição e silos, em 17 estados das cinco regiões brasileiras e no Distrito Federal, em meados da segunda década do século xxi. Além disso, seus produtos chegavam a cerca de $70 \%$ dos lares brasileiros.

Uma das características da Sanbra foi sua atuação no mercado nacional e internacional. Neste caso, tornou-se uma das maiores exportadoras do agronegócio e fez das vendas externas um de seus pontos fortes. No entanto, na medida em que o mercado nacional foi se consolidando, percebe-se uma nítida mudança de postura, com o declínio das atividades exportadoras. O auge das exportações ocorreu em 1973-1974, quando representaram 48.9\%, caindo para $21.4 \%$ no início da década de 1990.

Através da Sanbra é possível analisar o comportamento de um grupo econômico presente, há muito tempo no mercado interno. Percebe-se que atuou preocupada no longo prazo, fazendo com que, em 2014, a filial brasileira representasse 38\% do faturamento da Bunge mundial. Fez isso reinvestindo seu capital, aumentando a capacidade produtiva, diversificando produtos e lançando novos, ocupando o espaço nacional, adaptando-se às conjunturas econômico-políticas e, muitas vezes, apresentando-se como empresa nacional, para beneficiar-se dos programas dos bancos públicos que ofereciam condições especiais.

Esta prática foi esclarecida no texto através das negociações levadas a cabo na conquista de empréstimos do BNDEs durante a década de 1950, assim como no caso do Banco de Desenvolvimento do Paraná, uma agência de fomento estatal. Apesar da Sanbra não estar nem entre as indústrias de base e, muito menos, entre os grupos privados nacionais, as boas relações com o poder instituído lhe conferiram acesso aos recursos dos bancos e demais instituições financeiras públicas.

Outro destaque, no caso da Sanbra, é que ela representou um dos momentos típicos do processo de "industrialização através da substituição de importações" no Brasil. O país não tinha indústrias produtoras de óleos vegetais e a Sanbra começou a produzi-los ainda na década de 1920; importava adubos e a companhia passou à sua produção; incentivou novos cultivares, com a melhoria nas sementes; incrementou a produção de outra oleaginosa, a soja e, quando aumentou a produção, tornou-se uma das maiores esmagadoras, produzindo farelo, torta, óleo, lecitina e outros derivados. 
Esta pesquisa da Sanbra abriu várias outras questões que poderiam se transformar em novas pesquisas, que passamos a enumerar. Uma primeira diz respeito ao vínculo que esta firma específica manteve ao longo de quase um século com sua controladora, a Bunge Brasil. Por sua vez, a Bunge Brasil estava (pelo menos até a mudança da sede mundial da Bunge da Argentina para o Brasil em 1975), intimamente ligada à Bunge y Born argentina.

A segunda questão a ser aprofundada em outras pesquisas diz respeito à estratégia de diversificação da Sanbra e da Bunge Brasil e relacioná-la com a diversificação implementada pela Bunge y Born na Argentina. Ambas as estratégias seguiram, ao que parece, uma trajetória semelhante, ressalvadas as diferenças e idiossincrasias das economias dos dois países.

A terceira questão relaciona-se ao processamento das matérias primas conduzida pela Sanbra. Trata-se de indagar se foi em função da disponibilidade destas matérias primas às quais a Sanbra tinha acesso no Brasil, como grande comercializadora de grãos e óleos vegetais ou, se era mais uma estratégia voltada à agregação de valor às mercadorias, numa visão de integração vertical.

Um quarto item a destacar é sobre a diversificação da Sanbra, tanto vertical como horizontal. Isso ocorreu por uma decisão interna à empresa ou a firma buscou responder às debilidades da própria economia brasileira e às 'falhas de mercado' que dificultavam seu acesso a insumos industriais essenciais a seu desenvolvimento? Era mais prático comprar de terceiros ou internalizar atividades industriais buscando evitar os altos custos de transação e de contratos?

O quinto item trata do processo de internacionalização da Bunge, que apresenta-se como um tema bastante complexo e exigiria uma pesquisa específica. A Bunge já começou sua trajetória relacionando-se com o mercado internacional de importação-exportação. Foi fundada em 1818 e já em 1859 mudou a sede de Amsterdam para Antuérpia, na Bélgica, mantendo Amsterdam como a primeira filial internacional. Em seguida, no final do século XIX e início do Xx a filial argentina superou em tamanho e rentabilidade a parte europeia da companhia, sem mencionar o forte crescimento no mercado estadunidense, asiático e africano. Portanto, as exportações da Bunge Brasil, assim como seu proceso de internacionalização, estão dentro deste contexto mais amplo, que deveriam ser estudadas à parte.

Um sexto tema é o estudo de "um grupo econômico -Sanbra- atuando como subsidiária de outro grupo econômico (Bunge Brasil) que, por sua vez, era filial de outro grupo econômico, Bunge y Born argentino". Trata-se de entender como se deu a evolução destes grupos em economias periféricas, formando conjuntos com mais de uma centena de firmas, porém conservando a flexibilidade de uma estrutura organizacional que é a de uma empresa de empresas. No caso brasileiro, aliás, nomes como: Sanbra, Moinho Fluminense, Moinho Santista, Tintas Coral, Santista Têxtil, só para lembrar alguns dos nomes das 127 firmas do grupo nos anos 1990, nada tinham de específico que pudessem ser identificados ao nome Bunge.

\section{REFERÊNCIAS}

Aldrighi, D. M. e Postali, F. A. (2010). Business groups in Brazil. Em A. M. Colpan, T. Hikino e J. R. Lincoln (eds.), The Oxford handbook of business groups (pp. 353-388). Oxford: Oxford University Press.

Alianza SIDALC. ([s.d.]). Recuperado de http://www.sidalc.net

Amsden, A. H. e Hikino, T. (1994). Project Execution Capability, Organizational Know-how and Conglomerate Corporate Growth in Late Industrialization. Industrial and Corporate Change, 3(1), 111-147. DOI: 10.1093/icc/3.1.111 
Amsden, A. H. e Hikino, T. (1997). South Corea: Enterprising Groups and Entrepreneurial Government. Em A. D. Chandler, F. Amatori e T. Hikino (eds.), Big Business and the Wealth of Nations (pp. 336-367). Cambridge: Cambridge University Press.

Araújo, A. e Sousa, E. (2015). Sanbra. Recuperado de http://cgretalhos.blogspot.com/

Ata da Assembleia Extraordinária da Sociedade Algodoeira do Nordeste Brasileiro (Sanbra). (1942). Diário Oficial do Estado de São Paulo.

Baer, W. (2014). The Brazilian economy: Growth and development. Boulder: Lynne Rienner Publishers, Inc.

Banco Nacional de Desenvolvimento Económico e Social. (1996). O BNDES (Brasil) e o plano de metas, 1956-1961. Rio de Janeiro: BNDES.

Barbero, M. I. (2013). Business groups during the Export-led growth period (1870-1914). Em G. Tortella y G. Quiroga (eds.), Entrepreneurship and growth: an international historical perspective (pp. 69-91). Houndmills: Palgrave Macmillan.

Barros, G. (2015). O desenvolvimento do setor siderúrgico brasileiro entre 1900 e 1940: Crescimento e substituição de importações. Estudos Econômicos (São Paulo), 45(1), 153-183. DOI: 10.1590/0101-4161201545153gbs

Bértola, L. e Ocampo, J. A. (2012). The economic development of Latin America since independence. Oxford: Oxford University Press.

Bini, D. L. C. (2009). Mudanças históricas e implicações sócio-espaciais na composição das atividades agropecuárias hegemônicas na região de Araçatuba(SP) (Dissertação de mestrado). Universidade de São Paulo, Brasil. DOI: 10.11606/D.8.2009.tde-03092009-155252

Boldrin, D. L. (2011). Diretrizes competitivas para o setor do algodão do estado de Mato Grosso: Desafios das próximas décadas (Dissertação de mestrado). Universidade Federal de Mato Grosso, Brasil.

Born, J. (2008). Interviewed by Andrea Lluch [audio]. Creating Emerging Markets Oral History Collection,Baker Library Historical Collections, Harvard Business School.

Bunge. Brasil (2012). A Bunge: Nossa História. Recuperado de http://www.bunge.com.br/

Bunge. Brasil (2013). História do Grupo Bunge. Centro de Memória Bunge: São Paulo.

Bunge. Brasil (2014). Relatório de Sustentabilidade. São Paulo: Autor.

Bunge. Brasil (2016). Histórico Setor Têxtil. Centro de Memória Bunge: São Paulo.

Calais, C. (2017). Entrevista de Silva, G. P. y Costa, A. J. [Entrevista a la Diretora executiva da Fundação Bunge]. Archivo privado.

Calicchio, V. (2001). Augusto Frederico Schmidt. Em A. A. Abreu (ed.), Dicionário HistóricoBiográfico Brasileiro Pós-1930. Rio de Janeiro: Fundacao Getulio Vargas.

Caputo, A. C. e Melo, H. P. (2009). A industrialização brasileira nos anos de 1950: Uma análise da instrução 113 da SUMOC. Estudos Econômicos (São Paulo), 39(3), 513-538. DOI: 10.1590/S0101-41612009000300003

Carney, M., Gedajlovic, E. R., Heugens, P. P., Essen, M. V. e Oosterhout, J. H. V. (2011). Business group affiliation, performance, context, and strategy: a meta-analysis. The Academy of Management Journal, 54(3), 437-460.

Carteira de Comércio Exterior do Banco do Brasil (1971). Relatório da Carteira de Comércio Exterior do Banco do Brasil. Brasília: Autor.

Chandler, A. D. (1962). Strategy and structure: chapters in the history of the industrial enterprise. Cambridge: MIT Press. 
Coban, A. (2017). Business groups from emerging markets: new actors in international business. Em K. Ibeh, P. E. Tolentino, O. Janne e X. Liu (eds.), Growth frontiers in international business (pp. 103-119). Londres: Palgrave Macmillan.

Colpan, A. M. e Hikino, T. (2010). Foundations of business groups. Em A. M. Colpan, T. Hikino e J. R. Lincoln. Em The Oxford handbook of business groups (pp. 15-66). Oxford: Oxford University Press.

Colpan, A. M., Hikino, T. e Lincoln, J. R. (eds.). (2010). The Oxford handbook of business groups. Oxford: Oxford University Press.

Costa, A. D. e Silva, G. P. (2018). Bunge and his first fiftieth anniversary in Brazil (1905-1955): The construction of an economic group. Investigaciones de Historia Económica, 14(3), 199-209. DOI: 10.1016/j.ihe.2016.07.019

Cunha, M. R. (1992). Apêndice estatístico. Em E. L. Bacha y R. Greenhill (eds.), 150 years of coffee. Rio de Janeiro: Salamandre.

Dean, W. (1971). A Industrialização de São Paulo, 1880-1945. São Paulo: Difusão Europeia do Livro.

Delios, A. e Ma, X. (2010). Diversification strategy and Business Groups. Em A. M. Colpan, T. Hikino e J. R. Lincoln (eds.), The Oxford handbook of business groups (pp. 717-742). Oxford: Oxford University Press.

Draibe, S. M. (1985). Rumos e metamorfoses: Um estudo sobre a constituição do Estado e as alternativas da industrialização no Brasil, 1930-1960. Rio de Janeiro: Paz e Terra.

Fishlow, A. (2013). Origens e consequências da substituição de importações: 40 anos depois. Em E. L. Bacha, M. B. D. Bolle e A. C. Pastore (eds.), O futuro da indústria no Brasil: desindustrialização em debate. Rio de Janeiro: Civilização Brasileira.

Franco, G. H. B. e Lago, L. A. C. (2012). O processo econômico. Em L. M. Schwarcz (ed.), A abertura para o mundo, 1889-1930 (pp. 173-238). Rio de Janeiro: Objetiva.

Gaggero, A. J. e Rougier, M. (2017). Los grupos económicos argentinos y la respuesta frente al arribo de las empresas multinacionales en la década de 1990. El caso de Madanes en la producción de aluminio. História Econômica \& História de Empresas, 20(2), 407-438. DOI: 10.29182/hehe.v20i2.479

Giambiagi, F., Villela, A. A., Castro, L. B. e Hermann, J. (eds.). (2005). Economia brasileira contemporânea. Rio de Janeiro: Elsevier/Editora Campus.

Gonçalves, R. (1999). Capital financeiro, bancário e industrial no Brasil. Economia e Sociedade, $8(2), 179-189$.

Green, R. H. e Laurent, C. (1989). El poder de Bunge \&̋ Born. Buenos Aires: Legasa.

Guillén, M. F. (2000). Business groups in emerging economies: a resource-based view. Academy of Management Journal, 43(3), 362-380. DOI: 10.5465/1556400

Khanna, T. e Yafeh, Y. (2010). Business Groups in emerging markets: paragons or parasites? In A. M. Colpan, T. Hikino e J. R. Lincoln (eds.), The Oxford handbook of business groups (pp. 575601). Oxford: Oxford University Press.

Kim, D., Kandemir, D. e Cavusgil, S. T. (2004). The role of family conglomerates in emerging markets: What Western companies should know. Thunderbird International Business Review, 46(1), 13-38. DOI: 10.1002/tie.10108

Leff, N. H. (1974). El espíritu de empresa y la organización industrial en los países menos desarrolalados: los grupos. El Trimestre Económico, 41(3), 521-541. 
Madi, M. A. C. (2007). A vanguarda do pensamento conservador: um estudo sobre as ideias economicas de Roberto Campos no periodo 1950-1964. Em T. Szmrecsányi y F. Coelho (eds.), Ensaios de história do pensamento econômico no Brasil. São Paulo: Atlas.

Mello, J. M. C. (2009). O capitalismo tardio: contribuição à revisão crítica da formação e do desenvolvimento da economia brasileira. Campinas: Universidade Estadual de Campinas.

Mendonça, D. M. e Costa, R. L. (2014). Importância e preservação do legado industrial: o caso do eixo industrial em presidente Prudente/SP. Anais do $3^{\circ}$ Colóquio Ibero-Americano Paisagem Cultural, Patrimônio e Projeto. Apresentado em Belo Horizonte. Belo Horizonte.

Morck, R. (2010). The riddle of great pyramids. Em A. M. Colpan, T. Hikino e J. R. Lincoln (eds.), The Oxford handbook of business groups (pp. 602-628). Oxford: Oxford University Press.

MPE cobra a revitalização de estrutura da Sanbra. Presidente Prudente. (2014). O Imparcial. Recuperado de http://www.imparcial.com.br/

Negri, B. (1996). Concentração e desconcentração industrial em São Paulo (1880 - 1990). Campinas: Universidade Estadual de Campinas.

Ocampo, J. A. e Ros, J. (2011). Shifting paradigms in Latin America's Economic Development. Em José Antonio Ocampo y J. Ros (eds.), The Oxford handbook of Latin American economics. Oxford: Oxford University Press.

Orenstein, L. e Sochaczewski, A. C. (1989). Democracia com desenvolvimento: 1956-1961. Em M. P. Abreu y D. D. Carneiro (eds.), A Ordem do progresso: cem anos de política econômica republicana, 1889-1989. Rio de Janeiro: Campus.

Pinto, M. N. (1969). Contribuição ao Estudo da Influência da Lavoura Especulativa do Sisal no Estado da Bahia. Revista Brasileira de Geografia, 31(3), 3-102.

Saes, A. M. (2010). Conflitos do capital: Light versus CBEE na formação do capitalismo brasileiro (1898-1927). Bauru: Universidade do Sagrado Coração.

Sanbra (1954). Histórico [Documento não publicado]. Centro de Memoria Bunge, Brasil.

Sanbra (1960). Relatório da Diretoria e Balanço Geral. Brasil: Sociedade Algodoeira do Nordeste do Brasil.

Sanbra (1968). Fábrica de óleo de mamona em Salvador. Atualidades SANBRA, 2.

Sanbra (1969). Fábrica de óleo em Maringá. Atualidades SANBRA, 2(12), 4.

Sanbra (1970a). Construção de um parque industrial: bairro de Jaguaré. Atualidades SANBRA, $3(13), 6$.

Sanbra (1970b). Distribuição da rede de unidades. Atualidades $S A N B R A$, 3(16), 3, 5 e 15.

Sanbra (1971). Planta industrial de Recife. Atualidades SANBRA, 4(19), 7.

Sanbra (1972). Logística de embarque. Atualidades $S A N B R A, 5(25), 6$.

Sanbra (1973a). História da mamona. Sanbra 50 anos. Separata de Atualidades SANBRA, 6(34).

Sanbra (1973b). História do algodão. Sanbra 50 anos. Separata de Atualidades SANBRA, 6(31), 12 e ss.

Sanbra (1973c). História do amendoim, oiticica e babaçu. Sanbra 50 anos. Separata de Atualidades SANBRA, 6(36).

Sanbra (1973d). História do café. Sanbra 50 anos. Separata de Atualidades SANBRA, 6(35), 17.

Sanbra (1973e). História do milho. Sanbra 50 anos. Separata de Atualidades SANBRA, 7(32), 4.

Sanbra (1975a). Cadeia produtiva. Atualidades SANBRA, 8(3), 23.

Sanbra (1975b). Fábrica de óleos em Campina Grande. Atualidades SANBRA, 8(6), 22. 
Schneider, B. R. (2010). Business groups and the state: The politics of expansion, restructuring, and collapse. Em A. M. Colpan, T. Hikino e J. R. Lincoln (eds.), The Oxford handbook of business groups (pp. 650-669). Oxford: Oxford University Press.

Sediyama, A. F., Castro Júnior, L. G., Calegario, C. L. e Siqueira, P. H. (2013). Análise da estrutura, conduta e desempenho da indústria processadora de soja no Brasil no período de 2003 a 2010. Revista de Economia e Sociologia Rural, 51(1), 161-182.

Serra, J. (1982). Ciclos e mudanças estruturais na economia brasileira do pós-guerra. Em L. Belluzzo y R. Coutinho (eds.), Desenvolvimento capitalista no Brasil (vol. 2). São Paulo: Brasiliense.

Shurtleff, W. e Aoyagi, A. (2009). History of soybeans and soyfoods in South America (1882-2009). Lafayette: Soyinfo Center.

Shurtleff, W. e Aoyagi, A. (2016). History of lecithin and phospholipids (1850 to 2016): Extensively annotated bibliography and sourcebook: including phosphatides and liposomes. Lafayette: Soyinfo Center.

Silva, G. P. e Costa, A. J. (2015). Da falência à liderança: a trajetória do Grupo Votorantim no setor têxtil paulista (1918-1939). Anais do XLIII Encontro Nacional de Economia [Proceedings of the 43rd Brazilian Economics Meeting]. Apresentado em Florianópolis. Florianópolis: Associação Nacional dos Centros de Pós-Graduação em Economia.

Tavares, M. C. (1977). Da substituição de importações ao capitalismo financeiro: ensaios sobre economia brasileira. Rio de Janeiro: Zahar.

Trindade, C. M. (2017). Grupos econômicos argentinos: expansão e estratégias nos anos 2000 (Dissertação de Mestrado). Universidade Estadual de Campinas, Campinas.

Valdaliso, J. M. (2002). Grupos empresariales, marco institucional y desarrollo económico en España en el siglo xx: Los negocios de la familia Aznar (c. 1937-c. 1983). Revista de Historia Económica / Journal of Iberian and Latin American Economic History, 20(3), 577-624. DOI: $10.1017 / \mathrm{S} 0212610900010041$

Valor de mercado das empresas abertas (1988). Revista Bolsa, 1, 829.

Wendell, M. (1936). O monopólio e a desnacionalização de nossa indústria algodoeira [O discurso proferido na Assemblé Legislativa do Estado pelo deputado Mariano Wendell]. Correio Paulistano, 83(24.742), 9.

Willis, E. J. (2014). An enduring pocket of eectiveness: the case of the National Development Bank of Brazil (BNDE). Em M. Roll (ed.), The politics of public sector performance (pp. 94-116). Nueva York: Routledge.

Yaprak, A. e Karademir, B. (2010). The internationalization of emerging market business groups: An integrated literature review. International Marketing Review, 27(2), 245-262. DOI: $10.1108 / 02651331011037548$ 